


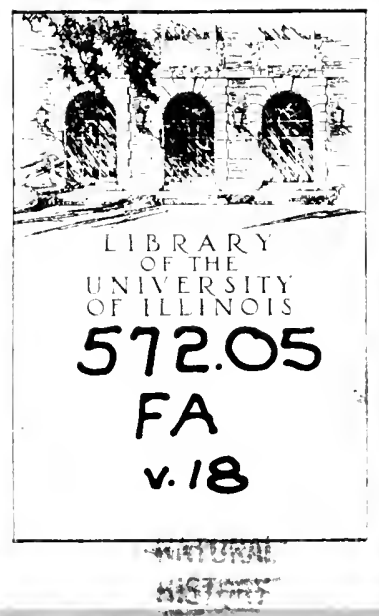




\section{CENTRAL CIRCULATION AND BOOKSTACKS}

The person borrowing this material is responsible for its renewal or return before the Latest Dafe stamped below. You may be charged a minimum fee of $\$ 75.00$ for each non-refurned or lost ifem.

Theft, mutilation, or defacement of library materials can be causes for student disclplinary action. All materials owned by the University of lilinois Library are the property of the State of Illinais and are profected by Article $16 \mathrm{~B}$ of Illinois Criminal Law and Procedure.

TO RENEW, CALL (217) 333-8400.

University of Illinois Library at Urbana-Champaign

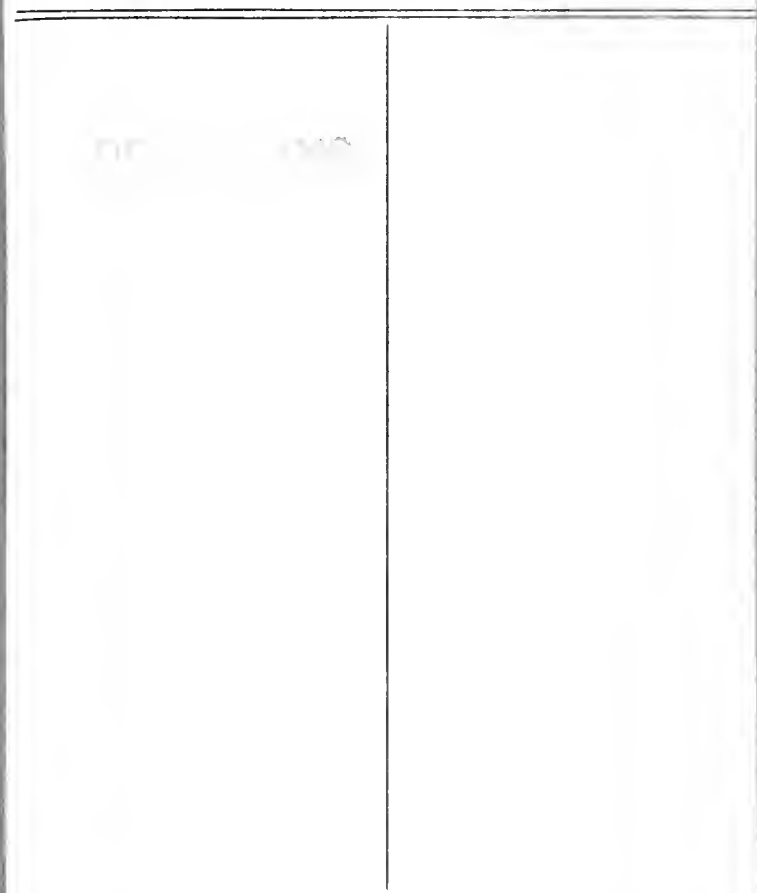

When renewing by phone, write new due date below previous due date. 


\section{THE LIBRARY OF THE \\ UNIVERSITY OF ILLINOIS}


v. $18^{3}$

\title{
Field Museum of Natural History
}

Founded by Marshall Field, 1893

\section{Publication 300}

\author{
ANTHropoloGical SERIES \\ Volume XVIII, No. 3
}

\section{THE DOMESTICATION OF THE CORMORANT IN CHINA AND JAPAN}

\author{
BY \\ BERTHOLd LAUFER
}

CURATOR, DEPARTMENT OF ANTHROPOLOGY

CURATOR, DEPARTMENT OF ANTHROPOLOGY

$\longrightarrow$

4 Plates in Photogravure
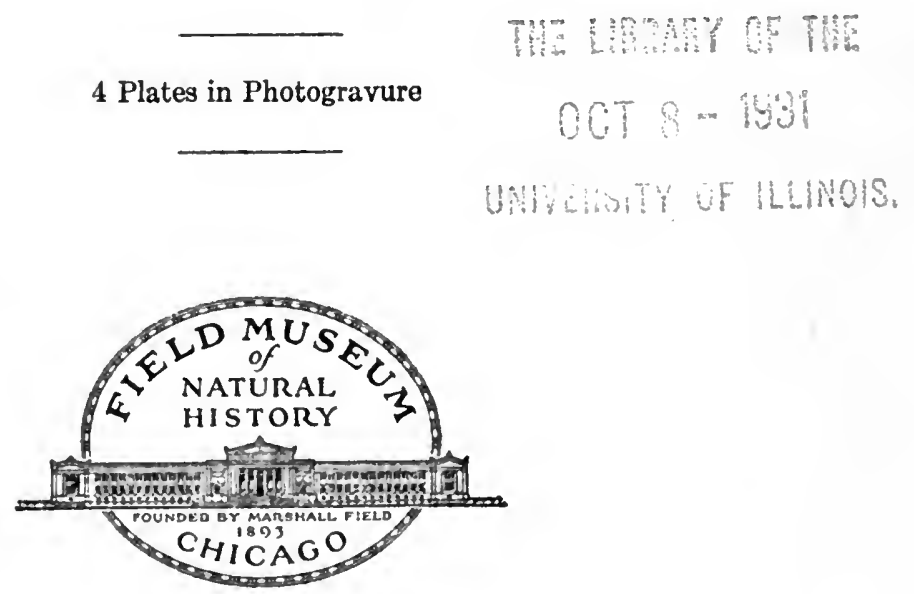

CHICAGO, U. S. A.

1931 



\section{Field Museum of Natural History}

Founded by Marshall Field, 1893

Publication 300

ANTHROPOLOGICAL SERIES

Volume XVIII, No. 3

\section{THE DOMESTICATION OF THE CORMORANT IN CHINA AND JAPAN}

BY

BERTHOLD LAUFER CURATOR, DEPARTMENT OF ANTHROPOLOGtHE LIBRARY OF THE

OCT $8-1931$

4 Plates in Photogravure

UNIVERSITY OF ILLINOIS.

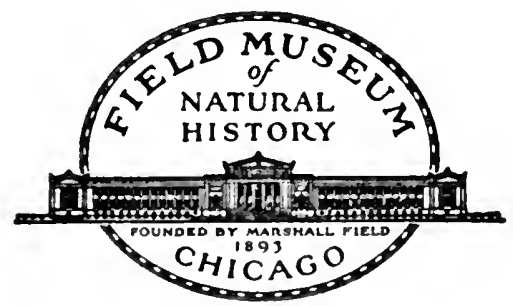

CHICAGO, U. S. A.

1931 
PRINTED IN THE UNITED BTATES OF AMERICA BY FIELD MUSEUY PRESS 


\section{FA \\ v. $18^{3}$}

CONTENTS

\begin{tabular}{|c|c|}
\hline List of Illustrations. & $\begin{array}{l}\text { PAGE } \\
203\end{array}$ \\
\hline . & 205 \\
\hline & \\
\hline gy. & 1. \\
\hline & \\
\hline aphical Distribution................... & 2 \\
\hline anese to Chinese Cormorant Fishing... & 2 \\
\hline The Process & 23 \\
\hline Relation of Cormorant to Otter Fishing and Egret Taming. & 24 \\
\hline Iconography $\ldots \ldots \ldots \ldots \ldots \ldots \ldots \ldots \ldots \ldots$ & 25 \\
\hline morant. & 25 \\
\hline & \\
\hline 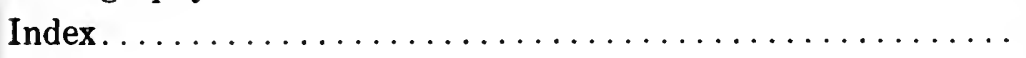 & \\
\hline
\end{tabular}





\section{LIST OF ILLUSTRATIONS}

XIII. White Porcelain Jar, Yung-cheng Period (1723-35). With painting in enamel colors of a fisherman carrying two cormorants on a bamboo pole. Cat. No. 180387. Presented by American Friends of China, Chicago.

XIV. Cormorant Fisher. Finger-painting by Kao K'i-p'ei. Dated 1665.

XV-XVI. Cormorant Fishing on Bamboo Raft on Min River near Fuchow, Fu-kien Province. Photographs taken by Mr. Floyd Tangier Smith.

Vignette on page 205. Jade Carving of a Cormorant of the Chou Period. Cat. No. 183296. 



\section{THE DOMESTICATION OF THE CORMORANT IN CHINA AND JAPAN}

\section{INTRODUCTION}

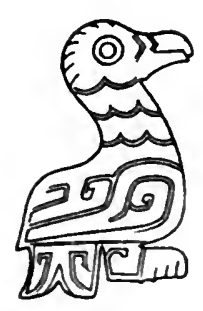

However much has been written on cormorant fishing in China and Japan, beginning with Friar Odoric of Pordenone, no one has ever made a serious study of the subject, nor has any one ever consulted the Chinese sources relating to it. The present study attempts to fill this gap. For more than twenty-five years I have been interested in the domestications of animals, especially in problems as to when, where, how, and why domestications originated and developed. In the course of these studies when I perused all general books on domestications and a great many monographs on specific subjects, I was struck by the fact that China and Japan are hardly mentioned in this literature and, if so occasionally, data and conclusions are usually wrong. This state of affairs should not be allowed to continue. The Chinese have preserved a vast amount of interesting material, both in literary records and works of art, bearing upon domesticated animals, which if properly used and correctly interpreted, is bound to be of great service to our science.

The problem of the domestication of the cormorant is the more interesting, as it is a typically and characteristically Chinese domestication. Of all nations of the world, the Chinese is the only one that has brought the cormorant into a complete and perfect state of domestication, the birds propagating and being bred in captivity. The fact is the more striking, as the cormorant is a cosmopolitan diffused over nearly the entire world, so that other nations had the same opportunity, but they did not seize it, nay, probably did not even see it. In Japan, the cormorant is semi-domesticated at present, but there is a possibility that there also it was truly domesticated in former ages. Here the interesting problem arises as to the relationship of Chinese and Japanese cormorant fishing, and it will be seen that it is a complex question which if studied at close range is widely different from what at the outset might be expected.

Dr. Gudger (I and II, consult Bibliography at end) has in recent years published two interesting articles on cormorant fishing in China and Japan. Being an ichthyologist and primarily interested in 
methods of fishing, he has treated the subject from this point of view and in a bibliographical manner. He passes in review, usually quoting the text completely, the more important accounts of cormorant fishing extant in European literature from Odoric down to recent times. Few of these accounts are of importance, or add much to our knowledge of the subject; most of them give surface observations of the fishing method, but say little or nothing about the cormorant itself. Fortune and Fauvel are praiseworthy exceptions and have given us data of scientific value. The more recent, the more stereotyped and duller the accounts of travelers become, and it is difficult to judge what is due to their own observations and what they copied from their predecessors. In the eighteenth and nineteenth centuries when China was merely a cabinet of curiosities in the eyes of European readers, cormorant fishing was not allowed to be wanting in any book on "China and the Chinese" and held its place alongside with birds' nests, dog and cat flesh, crippled feet, eunuchs, punishments and tortures.

Cormorant fishing was practised in Europe as a transient sport toward the end of the sixteenth or beginning of the seventeenth century when it appeared almost simultaneously at both the English and French courts.

James I took great delight in fishing with trained cormorants (as he did also in watching his tame otters, which were trained for a similar purpose), and John Wood was appointed "master of the royal cormorants." In 1618 the king decided to build a house and make ponds for his cormorants, ospreys, and otters at Westminster. In 1609 fishing cormorants were demonstrated at Fontainebleau before Louis XIII when he was dauphin. In the nineteenth century cormorant fishing was revived in England by Captain F. H. Salvin and in France by P. A. Pichot.

Harting (p. 427) holds that it is not unlikely that the sport was first made known in Europe by the Hollanders, who besides being enterprising navigators and traders in the East, have in all ages been known as skilful falconers and great bird fanciers. Likewise Pichot (p. 27) observes that cormorant fishing has come to us from the Far East and that it appears to have been introduced into Europe by the Hollanders in the beginning of the sixteenth century. Freeman and Salvin (p. 328) report two instances of cormorants having been brought to England from Holland, where they had been trained.

Yule (Cathay, new ed. by Cordier, II, p. 189) is mistaken in saying that the English bird was formerly used for fishing both in 
England and in Holland quite in the Chinese way. This, a priori, is utterly impossible, as the Chinese bird is thoroughly domesticated, while his European cousin was never domesticated, but merely trained for hunting fish.

In England the training of the cormorant was practised in adaptation of that of the falcon. The birds were hoodwinked when carried out of their enclosures to the fish-ponds so that they might not be frightened. The hoods were taken off on arrival at the fishing ground. When returning from fishing, the keepers called them to their fist, and the birds were carried on the gloved hand like a falcon. Nearly all the sportsmen of England and France interested in the cormorant were originally falconers. Thus Pichot (p. 27) admits that he learned the use of the cormorant from John Barr, a falconer from Scotland. This falconry method of cormorant fishing was never practised in China, and is peculiar to Europe. While it has but little interest to the student of cormorant domestication, the notes of European cormorant trainers like Harting, Salvin, and Pichot on the behavior of the bird are apt to offer him valuable suggestions.

Hunting with cormorants remained restricted to Holland, England, and France. In Germany where cormorants were occasionally hunted ( $\mathrm{J}$. Wimmer, Geschichte des deutschen Bodens, 1905 , p. 363) no attempts at training them were made; neither in Scandinavia. Olaus Magnus (Compendious History of the Goths, Swedes, and Vandals, 1558, p. 199) briefly describes the cormorant under the name "water-crow or eel-rook," but does not allude to fishing with cormorants.

The cormorant of China does not constitute, as was formerly assumed, a species of its own, being paraded under such hard names as Hydrocorax sinensis Vieillot, or Pelecarus sinensis Latham, or Phalacrocorax sinensis. According to Armand David (Les oiseaux de la Chine, p. 532) and other ornithologists, the Chinese cormorant is identical with that of Europe, and must simply be termed Phalacrocorax carbo Schr. Swinhoe. The species is diffused as far north as Kamchatka, and is very common along the entire coast of China and on lakes and rivers in the interior of the country, as well as in Mongolia. Moreover, this species is widely distributed along the Atlantic coast of North and South America, in South Greenland, Iceland, the Faroe Islands, Europe, Asia, Africa, Australia, and New Zealand. 


\section{CHINESE TERMINOLOGY}

跔 $i$, 獻第 $l u$-ts' $e$ (written language), also pronounced $l u$-se, Phalacrocorax carbo. The Er ya 爾 雅 gives the name of the cor-

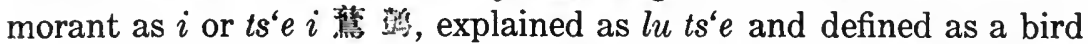
“with a beak curved like a hook and subsisting on fish”觜角曲如 鉤食魚.

Li Shi-chen 李時珍, in his Pen ts'ao kang mu本草網目, cites the Yün shu 韻 書 (cf. Watters, Essays on the Chinese Language, p. 40) to the effect that both $l u$ 盧 and tse 茲 mean "black," and that these names are conferred upon the bird with reference to its deepblack color (cf. 黝 tse, "black"). This explanation goes back to the Ts'ang kie p $p^{6}$ ien 蒼頡篇, on which see Watters, Essays, p. 26, and Pelliot, Le Chou King, Mém. concernant l'Asie Orientale, II, 1916, p. 137). According to the Pen ts'ao, the word $i$ (in some editions written 韵) is the cry or call of the bird itself (鹳者其馨自呼也), and was hence adopted as the name for the bird.

S. Wells Williams (Chinese Repository, VII, 1839, p. 54) asserts that the etymology of $l u t s^{\prime} e$ is "the black [bird] in the reeds." Evidently he thought in this connection of 盧 $l u$ ("a kind of reed"), but I am not aware of the fact that this derivation is given by any Chinese author. The supposition given above seems quite plausible, and the bird's name would simply mean "the black one."

In Lo-lo-p'o, one of the Lo-lo dialects, the cormorant, according to Liétard, is called $v \imath$-dzö-mo. The element $d z \ddot{0}$ obviously corresponds to Chinese 䳡, anciently $d z i$ (Shanghai $z e$ ).

The $Y i$ ts'ie king yin $i$ 一切 經音義 (chap. 19, p. 1b), compiled by Hüan Ying 玄 應 toward the middle of the seventh century, defines the cormorant after the Tse lin 字林 as "resembling the $i$ 盆鳥 (Giles No. 5490, 'the fish-hawk'), but being black, an aquatic bird with a beak curved like a hook and subsisting on fish, also called shwi ya 水鴉 ('water crow')." The latter term corresponds in meaning to our cormorant, derived from Med. Lat. corvus marinus ("sea-crow." Cf. German wasserrabe, seerabe; Dutch waterraaf).

The Mong liang lu 夢梁錄, written by Wu Tse-mu 吳自牧 (chap. 18, p. 15) of the Sung in A.D. 1274, classes the cormorant among the birds of Hang-chou under the name $l u$-ho 膚 鴊, adding that it is also called $l u-t s^{\prime} e$.

A synonym for the cormorant given in the Pen ts ${ }^{6} a o^{k}$ kang $m u$ and in several gazetteers of Fu-kien Province (e.g. Hing-hua fu chi 
興化府志, chap. 14, p. 9) is 蜀 水花 Shu shwi hua, i.e. “water flower of Shu" (Se-ch'wan). In the Ch'ang-t'ing hien chi 長 汀䅫志 (chap. 30, p. 58) this name is explained as referring to the cormorant's dung, which is used as medicine; it is ground to a powder with water, and when administered to a man, has the effect on him that he will give up wine.

慈老 $t^{\prime}$ ' $\mathrm{lao}$, in the Gazetteer of the District of Ch'ang-t'ing (chap. 30, p. 58).

青㱆 ts'ing lu, 涉鳥 kiao lu, in Palladius' Chinese-Russian Dictionary (also Giles, No. 1316).

Designations of the bird in the colloquial language are:

鳥頭網 wu t'ou wang, "black-headed net" (Ts'ing $i l u$, tenth century, see below, p. 221).

水老鴨 shwi lao ya, “aquatic old duck" (Pen ts'ao yen $i$, A.D. 1116).

水老鵢 shwi lao ya, “aquatic old crow." Especially used in Che-kiang.

魚鴉 yü ya, "fish crow."

釣魚 郎 kou yü lang, "fish-catching gentleman." Giles (Glossary of Reference, p. 96) remarks that this name is borrowed from that of the kingfisher.

摸魚公 mo yü kung, "Mr. Fish-diver."

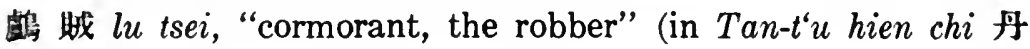
徙䅫志).

鳥鬼 wu kwei, "black devil." This local Se-ch"wan term is discussed in detail below (p. 214). While in the famous passage of $\mathrm{Tu} \mathrm{Fu}$ this term in all probability does not denote the cormorant, it has been made to denote the bird from the Sung period onward. This term reminds us of Milton's (Paradise Lost, IV, 196) comparison of Satan with a cormorant ("and on the tree of life, . . . sat like a cormorant"). A. Newton (Enc. Brit., VII, p. 162) thinks that this similitude is prompted by the bird's habit of sitting on an elevated perch, often with extended wings, and in this attitude remaining motionless for a considerable time as though hanging itself out to dry.

魚鹰 yü ying, "fish," or rather, "fishing falcon" (in northern China, particularly Shan-tung and Chi-li). This term properly denotes the fishhawk or osprey, and at Peking and Tientsin is especially applied to the common tern (O. F. von Möllendorff, Vertebrata, pp. 77, 102).

It is an interesting fact that the cormorant appears in several place-names. According to the Geography of the Ming (Ta Ming $i$ 
$t^{\prime} u n g$ chi), as quoted in Pien tse lei pien (chap. 210, p. 5), there is a Cormorant Cliff (Lu-ts'e Yen 孷, a hundred $l i$ west of King-ning hien 景寗䅫 in the prefecture of Ch'u-chou 處州府, Che-kiang; there is a spring there a drink from which would cure disease; subsequently it was struck by a bolt of lightning and formed a pool; there were fishermen who dared not cast their nets in it. A Cormorant Lake (Lu-ts'e Hu 湖) is located forty $l i$ southwest of Hai-yen hien 海監䅫 in the prefecture of Kia-hing 嘉與, Che-kiang, and measures over forty $l i$ in circumference. A Cormorant Embankment (Lu-ts'e Pei 陂) existed on the River Yüan 洹 水 in the district Nei-hwang 內黄, which formerly belonged to Ta-ming fu 大名府, Chi-li (now to Chang-te fu 彰德 府, Ho-nan), five $l i$ southwest from the old city of Nei-hwang, measuring eighty $l i$ in circumference; it was an advantageous place for fishing, protected by the natives. A Cormorant Islet (Lu-ts'e Chou 洲) is located in the district Shangkao 上高 in the prefecture Jui-chou 瑞 州 府, Kiang-si, east of the Lo-han Rock 羅漢石.

The earliest European illustration of a Chinese cormorant and fishing-boat is contained in Johan Nieuhoff's Dutch Embassy (1669, p. 134), and is titled "the bird Louwa." As this is Dutch spelling, the diphthong $o u$ is the equivalent of $a u$. The author does not give any European name. A. A. Fauvel (La Province chinoise du Chantoung, p. 293, Bruxelles, 1892) identifies this louwa with lao-wa which he says is still current in China. I have never heard this word, and have in vain looked for it in dictionaries. I imagine that it should be written 老萑 lao wa, wa being a name for the heron with which the cormorant is sometimes confounded. E. H. Parker (Up the Yangtse, p. 270, Shanghai, 1899) states that he heard the cormorant call lao wa in the upper Yangtse region. In Mesny's Chinese Miscellany (IV, 1905, p. 228) the cormorant is called shwi-lao-wa.

In Yen-chou, Che-kiang, according to an observation of E. H. Parker (J. China Br. R. A. S., XIX, 1885, p. 40), the heron (lu-se 䉆䉆) is called the cormorant, and the cormorant (gang ngo 銜我) the heron. I note from R. S. Maclay's Dictionary in the Foochow Dialect (p. 505, Foochow, 1870) that in Fu-chou colloquial the cormorant is lo li or lo si, lo being 鷖 $l u$ (“heron"). 


\section{JAPANESE TERMINOLOGY}

$u$ (a native Japanese word) 鸺, Phalacrocorax carbo. This character, read $t^{t} i$ in Chinese, refers in China to the pelican. It is not exactly clear why this character was adopted in Japan for the designation of the cormorant, but it is intelligible since pelican and cormorant are closely allied birds, both belonging to the Palmipedes. R. Hemeling, in his English-Chinese Dictionary (1916), assigns to $t^{i} i$ the meaning "cormorant." I do not know whether or in how far this is correct.

shimatsu 島津 (Manyōshu), 跑第, P. capillatus.

umi-u, $P$. capillatus.

hime- $u$ 姬鶇, $P$. pelagicus.

chishima- $u$ 千島鵜, P. bicristatus.

kawatsu, $P$. carbo hanedae Kuroda, a smaller species caught mainly on the coast of Tōkyo Bay and used for fishing in the streams near Tōkyo.

$u$-bune 鶇 船, a boat used in fishing with cormorants.

$u$-kai 鵜 饲, cormorant fisher.

$u$-tsukai 鵜 遣 饲, do.

$u$-nawa 鵜䋥, a line or straw rope used in cormorant fishing.

eboshi 鳥帽子, head-dress of the cormorant-trainer.

$u-j o$, chief cormorant-trainer. 


\section{HISTORICAL DATA}

The earliest mention of the use of trained cormorants for fishing occurs in the Chinese Annals of the Sui Dynasty (A.D. 590-617), but with reference to Japan.

In the Sui shu (chap. 81, p. 7) it is on record that "in Japan they suspend small rings from the necks of cormorants, and have them dive into the water to catch fish, and that they can catch over a hundred a day" (倭國以小環挂覻䉥項命入水捕魚日得 百 餘頭).

This brief information presumably given by the Japanese envoy who visited the Chinese court in A.D. 607 (cf. O. Nachod, Geschichte von Japan, I, pp. 207, 270) conveys the impression that this method of fishing was a novel affair to the Chinese chronicler. It is curious that neither at the time of the Sui nor under the $\mathrm{T}$ 'ang do we have a single account relating to this matter, so far as China is concerned. The only historical text cited in the cyclopaedia T'ai p'ing yü lan 太平御覽 (chap. 925, pp. 8b-9a), published by Li Fang 李昉 in A.D. 983, is the above passage of the Sui shu, while three other texts quoted there have merely reference to superstitions or medical prescriptions in reference to the bird, but not a word is said about its being trained in China. The same holds good for the T'u shu tsi ch'eng, where the historical notices of the bird 紀 事 open with the text of the Sui Annals, while the Ts'ing $i$ lu 清異錄 of the tenth century is given as the first record of trained cormorants in China.

The information given in the Sui shu is amply confirmed by Japanese sources. The cormorant ( $u$ 鵜) was utilized for fishing in ancient Japan. In the Kojiki 古事記, completed in A.D. 712, the Emperor Jimmu 神武天皇 addresses in a poem "the keepers of cormorants, the birds of the island" (translation of B. H. Chamberlain, p. 144). The same poem, which in Chamberlain's opinion probably dates from a far earlier age, is found in the Nihongi 日本記 of A.D. 720 (translation of W. G. Aston, I, p. 126). In the same work we meet the son of Nihe-motsu 包苴誩, who was the first ancestor of the cormorant-keepers ( $u-k a h i$ or $u-k a i)$ of Ata (ibid., p. 119) 阿太羑擄部始祖. Again, an allusion to cormorants "diving into the water to catch fish" is made in the same chronicle under the year A.D. 459 (ibid., p. 341).

Cormorants must have been abundant and popular in ancient Japan, and also played a role in mythology (K. Florenz, Quellen 
der Shinto Religion, p. 68). The father of the Emperor Jimmu

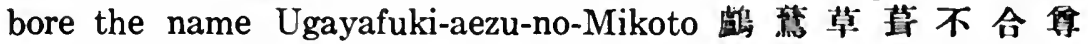
("Cormorant-rush-thatch unfinished."-Aston, Nihongi, I, pp. 95, 98). The lying-in hut (ubuya 屆) was thatched with cormorant feathers. In the record of a census made in A.D. 702 appears the name U-kai-be ("clan of cormorant-keepers") no Mezurame 鸺嚄 目都良賣 of the province of Mino. According to the Record of the Customs of the Province of Mino 美浱國新續䖝土記, there were during the period Engi 延喜 (A.D. 901-922) seven houses of cormorant fishermen on the Nagara River 長良川 in Mino; these prepared special dried ayu 鮎 (sweet-fish) for the use of the emperor and annually presented the fishes to the imperial household. The ayu is a salmonid about a foot in length and found only in the clear upland and mountain streams of central Japan. The Manyōshu

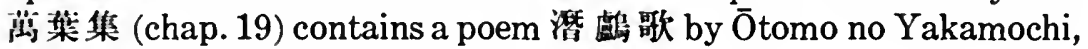
written in the province of Etchū.

Among the Hundred Laws of Ieyasu there is one (No. 24) in which it is said, "Formerly there were people who asserted that the hunt with cormorants and falcons should be abolished, and yet this is not an idle pleasure or a useless destruction of life. It is an old custom with the princes of China and Japan that they offer their hunting spoils to the emperor," etc. (T. Kempermann, Mitteilungen der deutschen Ges. Ostasiens, I, p. II).

Two Japanese scholars, Ikenoya (1917) and Kuroda (1926), have written treatises on the history of cormorant fishing in Japan, and excerpts from their data are given in E. W. Gudger's article "Fishing with the Cormorant in Japan" (see Bibliography at end).

Gudger (II p. 9) states, "So far as I have searched, unlike similar works for China, none of the early European voyagers to Japan, not even Kaempfer, figures or even refers to cormorant fishing in Japan." I have found, however, the following interesting note in the Diary of Richard Cocks (ed. of Hakluyt Society, I, p. 285) referring to the year 1617 :

"Soyemon Dono made a fishing over against English howse with cormorants made fast to long cordes behind their winges, and bridles from thence before their neckes to keepe the fish from entring their bodies, so that when they took it they could take yt out of their throates again." This is exactly the method still followed in Japan at the present time.

While there is good evidence for cormorant fishing in ancient Japan extending from the fifth and sixth to the eighth century, con- 
temporaneous evidence for China is entirely lacking. To be sure, ancient references to the cormorant in dictionaries, poetry, and the Pen $t s^{6} a 0$ literature are plentiful (see below, pp. 221 and 224), but these passages are reticent as to the training of the bird. The first and earliest document that contains a notice of trained cormorants used by man is the Ts'ing $i$ lu, a work of the tenth century (below, p. 221). It is supposed that a passage in a poem of $\mathrm{Tu} F \mathrm{Fu}$ alludes to domesticated cormorants; unfortunately, however, the bird does not appear there under its real name, but the phrase "black devil" is interpreted as such. This passage has been the subject of a lively controversy among Chinese authors, and I shall briefly review their opinions. At the same time we have occasion to touch upon several texts of the Sung period which refer to cormorant fishing.

In a poem of $\mathrm{Tu} \mathrm{Fu}$ 杜甫 (A.D. 712-770) the following verse occurs:

This means literally:

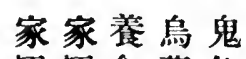
頓頓食黄魚

"All families (or: in the houses they) raise the black devil And at every meal feed on the yellow fish."

S. Wells Williams (Chinese Repository, VII, p. 542) translates, "Every family trains the black devil, which, often diving, seizes the yellow fish." The text, however, contains nothing about "diving" or "seizing." If wu kwei really be the cormorant, it may be admitted that the cormorant may occasionally feed on yellow fish; but if $w u$ $k w e i$, as interpreted by other scholars, is something quite different, this conception of the passage is absurd. It is quite clear that kia $k i a$ is the subject of the second clause and that the families eat the yellow fish. The latter is explained in the commentary to the Er ya as the name given east of the river 江 東 (i.e. in the lower Yangtse region) to the sturgeon, chan 鱣, which is from twenty to thirty feet long (Pien tse lei pien, chap. 135, p. 17b, where also the above passage from $\mathrm{Tu} \mathrm{Fu}$ is quoted, the title of the poem being given as 戲作俳 諧體詩. Cf. also Sü po wu chi 續博物志, chap. 2, p. 6, ed. of Pai hai). It is obvious that a cormorant can not catch a fish of the dimensions and weight of a sturgeon. The weight of a full-grown bird is about seven pounds, and a one-and-a-half pound fish is about the maximum weight a bird can carry. Long after I wrote this, I found in the T'ung ya 通 雅 (chap. 45, p. 21b) that Ma Yung-k'ing 馬永缴, who lived in the first part of the twelfth century, has made the same criticism ("Can a cormorant catch a yellow fish?" And Fang I-chi 方以智, author of the T'ung ya, comments, "Why is it 
necessary that he catches yellow fish? Why should it not be a yellowcheeked fish 黄棘魚 hwang kia yiu [Möllendorff, Vertebrata, p. 107]?"). The Pien tse lei pien gives a quotation from another poem of Tu Fu, entitled "The Yellow Fish" (cf. also Neng kai chai man lu, chap. 6, p. 23) and cites the $Y u$ yang tsa tsu as saying that in Shu (Se-ch'wan), whenever a yellow fish is killed, it will invariably rain.

The phrase "black devil" (wu kwei) has aroused much comment from authors of the Sung period; and, it will be seen, is credited with several different meanings. The general situation is well summed up by Wang Mou.

Wang Mou 王森, in his Ye ko ts'ung shu 野客满書 (chap. 26, pp. $5 \mathrm{~b}-6$, ed. of Pai hai), the preface of which is dated A.D. 1202, has the following discourse on the subject under the heading $W u$ kwei ("Black Devil"):

"As to the line of old Tu 'in the houses they raise the black devil,' there are several explanations. The Lan chen tse 濑黄子 [by Ma Yung-k'ing 馬 永 卿: Wylie, Notes, p. 164] interprets wu kwei as 'pig.' Ts'ai Kwan-fu 蔡寬夫 [author of $T s^{\prime}$ 'ai shi shi hwa 蔡氏詩話, biography in Sung shi, chap. 356] explains it as 'the seven gods of the dark wilderness'烏野七神. The Leng chai ye hwa 冷荷信話 [by Hui Hung 惠 洪, end of eleventh century: Wylie, Notes, p. 164] regards it as 'the devils of the Black Man,'Wu Man kwei 烏鑘鬼. Shen Ts'un-chung [i.e. Shen Kwa 沈 括, A.D. 1029-93], in his Mong $k^{\prime} i$ pi t'an 夢溪篻談, the Siang su tsa $k i$ 緗䅈雜記, the Yï yin ts'ung hwa 漁隱叢話 [by Hu Tse 胡 仔 of the Sung], the Lu nung shi 陸農師, and the $P^{`} i$ ya 增雅 interpret it as the cormorant $\left(l u-t s^{\prime} e\right)$. These four explanations differ widely. However, solely the explanation of the Leng chai is correct. Referring to the chapter 'Record of the Southern Man' in the T'ang Annals 唐書南整傳, we read that 'they commonly esteem shamans and devils and in the great tribes they have Great Devil Chiefs 大鬼主, while in the families they establish a Small Devil Chief 小鬼主; the White Man (Pai Man) form a single clan, the Black Man (Wu Man) five clans; the latter are so called, because the dresses of their women are made of black silk, while those of the White Man are made of white silk.' Further, in examining the comment of the Leng chai, Liu Yü-si 劉禹錫 (A.D. 772-842), in his poem Nan-chung 南 中, says, “They sacrifice in excess to numerous dark devils 青 鬼, for white-haired men are scarce among the inhabitants.' There is another saying with reference to the so-called dark devils: The cause of the prestige of the Man tribes of the rivers and gorges of Kwang-nan rests on the fact that they have such names as dark devils and black devils. 
"In the lines of $\mathrm{Tu}$ the 'yellow fish' is antithetical to the 'black devil,' from which it follows that the devils of the Black Man are meant. Let us further examine a poem of Yüan Wei-chi 元微之 [i.e. Yüan Chen $\bar{兀}$ 积, A.D. 779-831], who says, 'In their rustic taste they prize frogs or clams; in their domestic worship, all serve the crow or raven' (隗味尤珍蛤家神悉事烏). Yüan Chen further says, 'In case of disease they carry a raven around in a procession, praising it as a demon; the sorcerers predict (the outcome of the disease) by means of a tile which with them takes the place of a tortoise (病赛烏稱鬼巫占瓦代鼠).' According to the commentary, the people of the south, when infected by a disease, carry a black devil around in a procession. These explanations are similar to, but not identical with that given above. As regards the Record of the Southern Man (in the T'ang Annals), the word wu g $⿹$ has the meaning 'black,' but in the poem of Yüan Chen, as the word $k o$ 蛤 is antithetical to $w u$ 烏, it must have the meaning 'raven'."

This discourse is instructive in many respects. We note above all what difficulties Sung authors had in correctly understanding and interpreting a passage in a $T$ 'ang poem and how widely divergent their opinions were. I do not see that we poor epigones can do much better. There is no doubt that wu kwei, apparently restricted to Se-ch'wan, had several different meanings during the Sung period. I shall give additional information from the sources cited by Wang Mou and likewise from others.

$W u k w e i$, as $\mathrm{Ma}$ Yung-k'ing informs us, was applied to pigs. This is confirmed by the Man sou shi hwa 漫叟詩話 (cited in Pien tse lei pien, chap. 207, p. 3b): “The people of Se-ch'wan are fond of pork, and all families there are engaged in the rearing of swine. Whenever they call their pigs, they emit the sound wu kwei 鳥鬼. Hence they call a pig wu kwei ('black devil')."

Hia-hou Tsie 夏侯節 (in the T'ung ya, chap. 45, p. 21b, he is called 臬太夫), a scholar living in the gorges of Se-ch'wan 峽中士人, is quoted as saying, "The black devil is a pig. Many families inhabiting the gorges serve the devils and raise a particular pig, not, however, to be sacrificed to the devils, as this would be useless, but they put this pig among the common herd, and from time to time call the devils and the pig, keeping them apart, and this is the proper thing to do" (Ning-hua hien chi, 㴓化䅫志, chap. 2, p. 128). In the T'ung ya, however, the same scholar is quoted as saying, "The black devil is a pig. The families raise a particular pig for the purpose of sacrificing it to the devils." If this be correct, the designation wu kwei for the sacrificial pig may have arisen from the fact 
that it was intended as a sacrifice to the $w u k w e i$. Yang Shen 楊 慎 (1488-1559) writes that the people in the gorges raise young chicks which, provided with copper or tin rings, are offered to the spirits, and these are called wu kwei (T'ung ya, chap. 45, p. 21b).

$W u$ kwei was also applied to the raven. Corvus torquatus is still designated “devil bird” 鬼舁 (Möllendorff, Vertebrata, pp. 88, 89).

Lo Yüan 羅 蕦, author of the Er ya $i$ (twelfth century), writes, "In the opinion of some people, the inhabitants of the defiles of Sech'wan term the cormorant wu kwei, but these folks, on the other hand, serve the raven and call it devil; hence wu kwei is not the cormorant” (或云陝人謂第鳥鬼然陝人乃事烏筬鬼非此 物 也). Regarding another explanation as "raven" see below, p. 219 .

On the other hand, it cannot be doubted that wu kwei began under the Sung to denote the cormorant, and Wang Mou cites four authorities to this effect. This, of course, does not mean that the cormorant can be interpreted into the passage of Tu Fu. Wang Mou, however, errs in listing Shen Kwa among the pro-cormorantists; on the contrary, as will be seen presently, Shen Kwa, is averse to this explanation. Wang Mou's misunderstanding is copied from the Leng chai ye hwa (chap. 4, p. 7b, ed. of Pai hai), which he quotes, and this error was probably caused by the fact that Shen Kwa cites the $K^{\prime} w e i$ chou $t^{\prime} u$ king which seems to be the first Sung work to explain wu $k w e i$ as cormorant and the text of which is given alike in the $P^{\prime} i$ ya and the Mong $k^{\prime} i$ pi t'an written between A.D. 1086 and 1093.

Shen Kwa, in his Mong $k^{\prime} i$ pi t'an (chap. 16, p. 1, ed. of Pai hai) writes as follows: “The scholar Liu K'o 士人 劉 克 extensively inspected strange writings. One day he lighted on a poem of $\mathrm{Tu} F u$ [as quoted above]. The general explanation of this passage now given

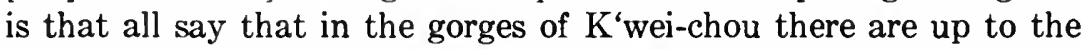
present time 'devil families' (kwei $h u$ 鬼 戸), and these are simply savages 乃夷人也; their chieftain is called a devil's chief (kwei chu 鬼主). However, I have never heard of a phrase like wu kwei 然不闑有鼠鬼之說. Moreover, as regards the devil families, these are the savages who are so called, but not something raised by man (as the cormorant is).

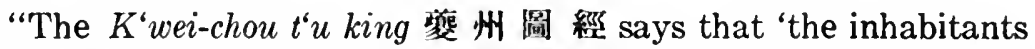
of the gorges of Se-ch'wan call the cormorant "black devil" (wu kwei) and that the people of Shu 蜀 人 dwelling along the water-courses raise this bird and fasten a cord to its neck whenever they send it into the water to dive for fish; when the cormorant has caught a fish, they pull him out of the water by means of this cord.' In this manner it is still practised up to this time, and I can testify to the 
truth of it, for I was in Se-ch'wan myself and saw people there raise cormorants $\left(l u-t s^{\prime} e\right)$ and employ them for the purpose of catching fish. Only I do not know that the people of Se-ch'wan call the cormorant black devil (但不知謂之鳥鬼耳).”

Here we have good and trustworthy testimony for domesticated cormorants in Se-ch'wan during the eleventh century. As to the term wu kwei, one man's word is as good as another's. Shen Kwa asserts merely that he did not hear the term used in Se-ch'wan for the cormorant, while others affirm they did. There is no reason to doubt that in the eleventh century wu kwei was a popular designation of the cormorant locally in certain parts of Se-ch'wan. We have no evidence, however, that this term was so used three centuries earlier during the lifetime of Tu Fu. No text of the T'ang period informs us that wu kwei then had the significance "cormorant." This is not a T'ang tradition, but a Sung tradition, and what happened was that Sung scholars who heard of that local usage interpreted this meaning back into the line of Tu Fu.

Fan Chen 范鋢, author of the Tung chai ki shi 東鵉記事, who lived in the latter part of the eleventh century, deserves special consideration as he was a native of Hwa-yang 華陽 in Se-ch'wan and must have been well informed on the affairs of his country. This work is reprinted in the Shou shan ko ts'ung shu, vol. 84, where his notice of cormorants is not given; it is cited, however, alike in the $T$ sing $k^{\prime}$ ang siang su tsa ki to be noted presently and in the Se-ch'wan $t^{\prime} u n g$ chi 四川通志 (chap. 74, p. 21), as follows:

"The fishermen of Shu raise cormorants to the number of ten and daily catch fish to the weight of ten catties. They tie a cord around the neck of the bird, so that a small fish may just pass through his throat, while he cannot swallow a big fish. From time to time the fishermen take the birds out of the water and let them dive into the water again. The birds are very tame, and will attend to everything as if they had a human heart. Whether they have caught a fish or not, they return to the boat, and those familiar with the flock will feed them and then cause them to return to their work. This method is comparable to falconry, but saves the trouble of riding on horseback and running. The profit obtained from this business is very large."

The Siang su tsa ki cited by Wang Mou is called with its complete title Tsing $k^{\prime}$ ang siang su tsa ki 靖康緗素雜記. This work, as implied by the title, was written in the Tsing-k'ang period (A.D. 1126-27), and is from the hand of Hwang Ch'ao-ying 黄朝英 of the Sung (cf. Wylie, Notes, p. 159: early twelfth century). It is reprinted 
in the Shou shan ko ts'ung shu, vol. 69, and the text in question, entitled $W u$ kwei, is in chap. 5, pp. 2b-3a (the T'ang Sung ts'ung shu contains only a greatly abridged form of this work of only thirteen pages, which does not contain this text). The author refers to the Mong $k^{\prime} i p i t^{\prime} a n$, saying that solely Liu K'o 劉 克 has explained the meaning of wu kwei correctly; then he cites the Tung chai ki shi, translated above, noting that its author, Fan, does not know either that the cormorant should be intended by the "black devil" of Tu Fu. Finally he cites the cormorant account of the Sui shu; and, I believe, he is the only Sung author who has done so and seen the identity of cormorant fishing in Japan and China. Judging from this text, Wang Mou is wrong in classifying Hwang Ch'ao-ying among writers who interpret Tu Fu's wu kwei as the cormorant; but in the Sech'wan t'ung chi 四川通志 (chap. 74, p. 21) Hwang is quoted thus: "The people in the gorges (of Se-ch'wan) call the cormorant 'black devil' and raise it for the purpose of catching fish, making cormorantfishing their business." If Hwang Ch'ao-ying should really have made this statement, which is not contained in the edition of the Shou shan ko ts'ung shu, and which contradicts the text of the latter, Wang Mou would be right.

Exactly the same information as in the Se-ch'wan $t^{\prime} u n g$ chi is given in the $K^{\prime}$ wei-chou fu chi 竞 州 府志, 1891, chap. 14, p. 4.

Wu Tseng 吳 曾, author of the Neng kai chai man lu 能改漫錄 (chap. 6, p. 21b; middle of twelfth century), cites the passage from Yuian Chen's poem with the commentary in the same manner as Wang Mou and decides that the wu kwei of $\mathrm{Tu} \mathrm{Fu}$ has the same meaning. He also attributes to Shen Kwa the notion that the wu kwei of $\mathrm{Tu} \mathrm{Fu}$ is the cormorant, adding, "I do not know on what evidence this is based” (不知文何所據也).

The opinion expressed in the Leng chai ye hwa (chap. 4, p. 7, ed. of Pai hai) is shared by Kwo T'wan 垶象 in his $K^{\prime}$ wei kü chi 聧車志 (Wylie, Notes, p. 197; after $T^{\prime} u$ shu tsi ch'eng; I have not been able to trace this passage in the edition of Pai hai), who denies that in Tu Fu's verse the term wu kwei refers to the cormorant, but who asserts that it alludes to the Black Man devils 鳥篎鬼 and that this is the only correct explanation. The Leng chai ye hwa says that "the people along the roads in the gorges of Se-ch'wan sacrifice to the devils of the Black Man." Fang I-chi adds this comment: "On the roads of Pa-tung 巴 束 there are ravens. People traveling by boat must throw away their meat and give it to the ravens as provision; otherwise they will have no luck. Should these ravens be the black devils?" 
In the Wen kien lu聞見錚 by Shao Po-wen 邵伯温 of the Sung dynasty it is said (Pien tse lei pien, chap. 207, p. 3b), "On the eleventh day of the first month of every year the people in the gorges of $K^{\prime}$ wei 熟陝之人 offer sacrificial animals and wine in the fields on behalf of Ts'ao Ts'ao 篇曹; on this occasion there is a drill of soldiers with a great deal of noise, and this they call 'raising the black devil" " 炎烏鬼. The Wen kien $l u$ is reprinted in the Tsin tai $p i$ shu and Hio tsin t'ao yüan to which I have not access at present.

It is certain that the term $w u k w e i$ hails from Se-ch'wan.

It cannot be said that the Sung writers who plead for wu kwei as the cormorant have made out a strong case in their favor. They are all obsessed with the sole passage of $\mathrm{Tu} \mathrm{Fu}$, and do not fall back on any other text. Above all, they fail to explain why wu kwei, a local Se-ch'wan colloquial term, was transferred to the cormorant. From their explanations it is perfectly clear why pig and raven came to be called "black devil." Here the relation of these creatures to devils or spirits is conspicuous; not so, however, in the case of the cormorant who lacks any association with the supernatural world. Why this useful helpmate of man who contributes so much to human economy should be dubbed a black devil is simply unintelligible.

Palladius (Chinese-Russian Dictionary, I, p. 127) explains $w u$ $k w e i$, "raven, as a demon. In the south of China, in case of any disease, the female shamans make an offering and divine by means of the tortoise. Swine-mother. Cormorant." Giles, in his Dictionary, gives merely the meaning "cormorant."

I shall not decide how the above verse of $\mathrm{Tu} F u$ is to be interpreted. I have merely reproduced the various opinions of Chinese authors from which it follows that the definition of wu kwei as "cormorant" in Tu Fu's verse is at least exceedingly doubtful. This study is not a contribution to Chinese poetry, but one to the domestication of the cormorant. As I have studied the latter subject for many years, I feel obliged to say that it seems to me most improbable that the cormorant can be understood in the passage of Tu Fu; for to say that "the families raise the cormorant" would imply that the domestication of the bird was quite general (at least in one part of China or the other) during the eighth century. Now, if this had been the case, we should assuredly expect to find other contemporaneous texts corroborating this matter, but no such text of the $\mathrm{T}$ 'ang period, as far as I know, has as yet come to the fore. It seems fairly clear that the interpretation of wu kwei as "cormorant" in Tu Fu's verse arose only in the Sung period when the subject of cormorant fishing became known to scholars, and personally I am 
convinced that the cormorant is not visualized by $\mathrm{Tu} F u$. But even if this were the case, it would simply be an isolated scrap of evidence to which no great historical significance can be attached. In my opinion the line of Tu Fu means, "The families when they perform the ceremony known as 'caring for the black devil,' feed (on this festive occasion) on sturgeon." To be sure, Tu Fu, like $\mathrm{Li} \mathrm{Po}$, Wang Wei, and other poets of the T'ang period, was familiar with the cormorant; he mentions it in a verse that begins 邪外第久不來, but here the bird appears under its regular name $l u-t s^{\prime} e$, and so it is designated by other writers, e.g. Yüan Chen (E. von Zach, Ein Briefwechsel in Versen, pp. 216,220). The salient point is that the cormorant is mentioned and discussed by Sui and T'ang authors, but there is dead silence on their part as to the domestication of the bird.

The $I w u$ chi 哄物志 of Yang Fu 楊 孚, which is possibly a work of the Sui dynasty, for instance, says that the cormorant dives in deep water in order to catch fish on which it subsists; it is a waterbird and nests in high trees. A superstition dealt with below under the heading "folk-lore" is added to the text, but nothing is said about the employment of the bird in the service of man.

In so-called classical literature the cormorant appears not to be mentioned. It is not referred to in the $K^{\prime}$ in king 唡 經 ascribed to Chang Hua 張華 (third century A.D.), nor in the Mao shi ts'ao mu niao shou ch'ung yü su毛詩草木鳥獸䖪魚疏 of $\mathrm{Lu} \mathrm{Ki}$ 陸璣 (A.D. 260-303).

The earliest text that mentions the cormorant as trained for fishing is contained in the $T s^{\prime}$ ing $i$ lu 清買錄 (chap. 上, pp. 57b-58), written by $\mathrm{T}^{\prime} \mathrm{ao} \mathrm{Ku}$ 缸 频, who lived in the tenth century (A.D. 902-970, according to Giles, Biogr. Dict., No. 1898):

"For the purpose of catching fish they use cormorants $\left(l u-t s^{\prime} e\right)$ which are quick and alert to a high degree. In the district of Tang$t^{t} u$ 常塗 there are ponds covered with aquatic plants and rocky hills, where people live scattered on farms and in cottages and raise cormorants in their houses 畜焦於家. They make a small boat fast on the bank and daily send a man - $丁$ to catch fish for the supply of the families. A municipal official (yi yï 色尉), when he passed this place, noticed it and said to the hill-people, 'The small boat is the arena for receiving the meat 小舟 師秋䏩埸; the cormorant is the small official (siao yü 小尉).' It is said also that the fishermen of the rivers and lakes use the cormorant and call it 'the small official.' Other fishermen bestow on the cormorant the epithet 'black-headed net' (wu t'ou wang 烏䫓 網)." 
Tang-t'u forms the prefectural city of T'ai-p'ing 太平府, An-hui Province, on the lower Yangtse. How little dependence can be placed on the T'u shu tsi ch'eng is shown by the fact that this important document is quoted therein in the following abbreviated form: "For the purpose of catching fish they use cormorants which are quick and alert to a high degree. The people therefore speak of the small boat as the arena for receiving the meat and of the cormorant as the small official." The locality and all the significant points of the story are coldly deleted. I allow this to stand as I wrote it, but afterwards when I consulted the edition of the T'sing $i l u$ in the T'ang Sung ts'ung shu (chap. 2, p. 13b), I found there to my surprise the text as given in the $T$ ' $u$ sh $u$. There must be, accordingly, different manuscripts of the $T s^{i} i n g i l u$.

The document in question is characteristic of the attitude of Chinese scholarship. Here we are confronted with the first mention of the domesticated cormorant on Chinese soil and might justly expect an expression of surprise or astonishment at so unusual an achievement, or an inquiry on the author's part into the origin of this extraordinary practice. It is simply taken for granted, however, without further comment. What the author is interested in is not the novel fact, but a literary bon mot for which his story serves as an explanation. In fact, his notice is entitled 納膾場 (腸 in the edition before me, printed in 1875 by 陳氏庸閒架, is a misprint) 小 尉, and it is this new, learned term that he is intent on introducing to his scholarly readers. This term has not proved a success, for it has not been adopted, so far as I know, by any subsequent author. The case is analogous to that of the Sung writers who got excited over the term wu kwei. The story itself is perfectly clear in demonstrating that during the tenth century the cormorant was domesticated and reared for catching fish in certain places of Tang-t'u, apparently out of the way and not easily accessible to officials, who noted merely the fait accompli without bothering about questions of origin and development. Simple folks, fishermen by avocation, had accomplished what an official would never have thought of; the process of taming and training the bird, ultimately resulting in its domestication, had remained unnoticed by the learned, and no record of it is preserved.

This philological attitude is characteristic of the Chinese scholarly mind. Words, phrases, characters, inscriptions, etc., have always found attention and were made the subject of profound studies, while the subject-matter itself was neglected. It is hardly conceivable that a matter so characteristically Chinese as the domesti- 
cation of the cormorant, which is an interesting scientific problem to us, has left Chinese scholars completely indifferent. Ch'en Hao-tse 陳 深 子, in his Hwa king 花 鏡, published in 1688, devotes chapter VI of his work to animals kept by man. Of birds he deals, for example, with crane, peacock, egret, parrot, falcon, eagle, pheasant, pigeon, etc., but the cormorant is not even mentioned. The $T s^{\prime} e$ yüan 源, now revered and quoted by European sinologists as a sort of Bible, exhibits the same defect, and in giving a superficial definition of the cormorant does not even mention the fact of its domestication or its employment in the human household; the term $w u k w e i$ is given as a synonym of the cormorant, but not even the passage of $\mathrm{Tu} \mathrm{Fu}$ is cited, nor is there any reference to the controversy which it has aroused!

In one respect T'ao Ku's story does not enlighten us. He does not describe the method of fishing itself, a subject which did not greatly interest him; and while he says that cormorants were reared in the habitations of fishermen in the Tang- $t^{\prime} u$ District, which indicates that the birds to some extent must have been domesticated in that locality at that time (about the middle of the tenth century), we are unable to judge to what degree the domestication of the birds had then progressed. Was it still in the primary stage? Or had it far advanced? The question is important, for we are anxious to know to what time the beginnings of this domestication go back. If it was in a perfect state in T'ao Ku's days, we have to concede that a considerable span of time must have elapsed before this state was reached; or, if it then was in its initial stages (and this is more probable), this concession becomes superfluous. 'T'ao Ku's succinct note does not give us a direct clue to the solution of this problem. While the domestication of the cormorant requires a great deal of patience and endurance, it is not excessively difficult, and in my estimation it is not necessary to date the preliminary steps leading to the domestication in China farther back than about the beginning of the tenth century. More will be said about this point in the chapter on the Process of Domestication.

The texts of the $K^{\prime}$ wei chou $t^{\prime} u$ king, Mong $k^{\prime} i p i t^{\prime} a n$, and Tung chai $k i$ shi have been quoted above. These refer alike to the province of Se-ch'wan, which has played an important role in the domestication of the cormorant, and agree in emphasizing the cord tied to the bird's neck-a sure sign of its domestication. There can be no doubt that during the Sung period it reached the state of perfection.

In the Er ya $i$ 雨雅翼, written by Lo Yüan 維願 in the twelfth century, it is stated, "At present there are in Shu (Se-ch'wan) many 
people inhabiting the water-courses who keep and raise cormorants by tying a cord around their necks. In this manner small fishes may pass the bird's throat, while it is unable to gulp down large fishes. From time to time the fishermen call the birds and relieve them of their fishes; then they are sent out again. They are so docile and familiar with man that signs are sufficient for them to grasp their masters' intentions. When they finally return to the boat, whether with fishes or without, they are detained and fed, and then are allowed to return home. This method is comparable to hunting with kites and sparrow-hawks without the trouble of hustling around. The profit from this business is rather large, for the fishermen raise several tens of birds and daily obtain several tens of catties of fish. The fishes coming out of the birds' throats have a strong odor, being affected by the unpleasant saliva of the birds [the cormorant pockets its prey in its oesophagus]. After they have come out of the water, the fishes are spread out on rocks and dried in the sun."

The attitude of the T'ang and Sung Pen ts'ao literature toward the cormorant, as far as its domestication is concerned, is negative. The Sin siu pen $t s^{\prime} \alpha o$ 新修本草 (chap. 15, p. $25 \mathrm{~b}$ of the facsimile edition published in Japan) does not give a definition or description of the bird; in fact, the article in question is not entitled "The Cormorant," but "The Cormorant's Ordure" 筧矢, with the synonym Shu shwi hwa; the ordure, it is said, removes black spots and pimples from the face; and this is followed by a quotation from T'ao Hung-king, who gives a bit of folk-lore concerning the propagation of the bird (below, p. 255). Ch'en Ts'ang-k'i 陳藏器, author of the Pen ts'ao shi $i$ 本草拾遗, does not go beyond this; and the Pen ts'ao yen $i$ strings its harp on the same note (text given below, p. 255). T'ang Shen-wei 唐憤微, in his Cheng lei pen ts'ao 證類本草 of A.D. 1108 (chap. 19, p. 19b), is not either interested in the cormorant itself, although he pictures it in a naively crude drawing. $\mathrm{He}$ is contented to reiterate the data of the Sin siu pen ts'ao. The T'ang and Sung herbalists, accordingly, restricted themselves to pharmacological and folkloristic notes without manifesting any real interest in the bird itself. The fact that the T'ang authors of Pen ts'aos are silent as to the bird's employment for fishing is, of course, inconclusive; the Sung Pentsaoists do not mention it either, although at their time this was an accomplished fact.

Li Shi-chen 李時珍, in his Pen ts'ao kang mu 本草網目, is the first herbalist who discusses the cormorant with some degree of intelligence: 
"Cormorants occur everywhere in districts where water is found. The bird resembles the fish-hawk ( $y i$ d latter. In color it is black like a crow. It has a long and slightly curved bill. It is expert in diving into water and catching fish. During the daytime the birds gather on islands; at night they roost in the trees of forests. The ordure of the birds is poisonous, and the trees on which for a long time they have perched will decay. The fishermen in the southern parts of the country keep them by tens, tying them together, and thus they catch fish for them. The passage in Tu Fu's poem that 'families raise black devils and at every meal feed on yellow fish' is referred by some to this species. There is another kind resembling the cormorant, but with a head like that of a snake, a long neck, and moulting during the winter; it roosts on the banks of mountain-streams, and at the sight of men is unable to walk and dives into the water. This is identical with what the Er ya calls yao t'ou 纤頭 or y ü kiao 魚鲛; it is not used in the pharmacopoeia."

This species, under the name yü kiao or simply kiao ("shark"), is also mentioned by $\mathrm{Ch}^{\prime}$ en Ts'ang-k' $\mathrm{i}$ of the $\mathrm{T}$ 'ang, who describes it as having a slender head and a long body and being white in the upper part of the neck (cf. Cheng lei pen ts'ao, chap. 19, p. 19b). The description of this species, as given by Li Shi-chen, is almost identical with that in the Er ya $i$, save that there the reference to the two names is wanting.

During the Ming period cormorant fishing appears to have been flourishing. Sü Fang 徐芳 of the Ming writes, without specifying localities, that "cormorants were reared by many people along the rivers, being carried on small rafts. Fishing was done in stagnant water or in places where the river formed eddies and where fishes congregated. The birds dived deeply into the water and swiftly brought up small fishes; when their strength failed in carrying big ones, they broke them up. A small ring was tied around their necks, so that they could not swallow fishes of large size; when they caught such, the fishermen took them away at once. Small fishes entered their throats as far as the spot where the ring was placed, but the birds could not swallow them on account of the bones. When the fishes had piled up and the birds were hungry, they were fed with a couple of fishes. The birds were greedy and insatiable, but the fishermen were satisfied and reaped a large profit" (text in $T$ ' $u$ shu tsi ch'eng, XIX, chap. 45, $i$ wen).

To the Buddhists, naturally, cormorant breeding and what is associated with it has been a thorn in the flesh. In a Buddhistic 
tract written in the colloquial language and published by L. Wieger (Moral Tenets and Customs in China, p. 203, Ho-kien-fu, 1913), the officials are urged to prohibit the keeping of cormorants as well as fishing or catching crabs. Here the term yï ying 魚鷹 is used. 


\section{GEOGRAPHICAL DISTRIBUTION}

The center of cormorant fishing is the lower Yangtse Basin including the provinces of An-hui, Kiang-su, and Che-kiang, the present T'ai-p'ing fu on the Yangtse being pointed out as early as the tenth century. The region around Lake T'ai ( $\mathrm{T}^{\prime} \mathrm{ai} \mathrm{hu}$ ) and the entire country intersected by a net of canals around Wu-si, Su-chou, Hang-chou, Chu chou, Shao-hing, Fung-hua, and Ning-po swarm with cormorants kept by fishermen. The easternmost point to which the trained cormorant advanced is Ting-hai on the Island of Chu-san (Ting-hai t'ing chi 定海廳志, chap. 34, p. 42). The most celebrated of the localities of Che-kiang is T'ang-si-chen, a small town situated 50 li northwest of Hang-chou, whose inhabitants are reputed to possess a secret which insures to them a decided success in the rearing of cormorants (Fauvel, p. 230). Nearly all district and prefectural gazetteers of the province allude to the industry; for example, Ts'ing-t'ien hien chi 青田䅫志 (1875, chap. 4, p. 29); Shao-hing fu chi 紹興 府志, chap. 11, p. 31; Ts'e-k'i hien chi 慈 䅫志, chap. 54, p. 9. In the region of Shao-hing and Ning-po I observed cormorant fishing many times in 1901.

From Che-kiang the practice spread to the province southward, Fu-kien. A careful examination of the prefectural and district gazetteers of this province in the Library of Congress has led me to the following result. Fishing with cormorants occurs all along the seacoast of Fu-kien from Fu-ning fu in the north down to Fu-chou, Hing-hua, Ts'üan-chou, and Chang-chou in the south, all along the Min River from Yen-p'ing to Fu-chou; further, in Lung-yen chou, Yung-ch'un chou, as far west as T'ing-chou fu (汀州 府志, chap. 8, p. 19) and as far north as Kien-ning fu. It may be said, therefore, that cormorant fishing is generally practised over the entire province.

As to Fu-chou, cormorant fishing was observed by R. Fortune (I p. 88) in 1843 and by G. Smith in 1845 in the suburb of Nan-tai (Chinese Repository, XV, 1846, p. 207). Freeman and Salvin (p. 328) also state that they met with people who saw it about Fu-chou fu, at the mouth of the river. Cormorant fishing is still actively pursued there.

The two coterminous provinces Che-kiang and Fu-kien have always exchanged cultural products, and most probably cormorant fishing spread from Che-kiang to Fu-kien. The Gazetteer of Hing-hua fu 與化 府志 (chap. 14, p. 6) in Fu-kien stresses the 
fact that "the people of Che-kiang are in the habit of raising cormorants who dive to catch fish, swallowing the small ones, but bringing the big ones to their master."

In Fu-chou, Fu-kien, it seems to be customary that when a bird has brought a fish to the surface, the boatman paddles his raft to the spot and casts a net into the river, hauling bird and fish on board (G. Smith, Chinese Repository, XV, 1846, p. 207). This unnecessary procedure goes to show that the fishermen in question had passed to the use of the cormorant from a former method of fishing with nets. J. Doolittle (Social Life of the Chinese, I, 1865, p. 55) intimates that the fishermen of Fu-chou take bird and fish out of the water with a dip-net only in case the fish is a large one and a struggle ensues between bird and fish.

In An-hui Province, to which our earliest Chinese account relates, the district of Wu-ho 五河䅫 enjoys a reputation for breeding cormorants (Korrigan, p. 39). This method of fishing is practised all along the Huai River 淮 河, which traverses Ho-nan and the northern part of An-hui.

As to the province of Kiang-si, we have observations of cormorant fishing made in the prefecture of Nan-an 南安 府 by Father Ripa in 1710 (F. Prandi, Memoirs of Father Ripa, 1844, p. 40). The $\mathrm{P}^{\prime} \mathrm{o}-\mathrm{yang}$ Lake in this province, as well as the Tung-t'ing Lake in the adjoining province of Hu-nan, swarms with fishermen who avail themselves of the cormorant. The birds coming from Hu-nan, as well as from Ho-nan, enjoy a special reputation. The district of Siang-yin 湘陰 in the prefecture of Ch'ang-sha, and $\mathrm{Li}$ chou 澧 州, as well, are emphasized as cormorant-breeding localities in the Hu-nan fang wu chi 湖南方物志 (chap. 2, p. 17; chap. 7, p. 14 . Regarding this work see below, p. 237).

In Kwang-tung Province cormorant fishing is practised at Ts'unghua 從化, in the prefecture of Kwang-chou (witnessed by J. H. Gray, China, II, 1878, p. 297). De Guignes (Voyages à Peking, Manille etc. faits dans l'intervalle des années 1784 à 1801, I, 1808, pp. 271, 289,293 ) observed in 1794 cormorant fishing in the prefecture of Shao-chou 韶州府. Dyer Ball mentions the North River above Canton and the river above $\mathrm{Ch}$ 'ao-chou fu 潮州 府.

Dr. Gudger (I pp. 37, 38) has reproduced two photographs taken by Dr. C. K. Edmunds in 1907 on the Fu River, a tributary of the Si Kiang or West River. Dr. Edmunds states that he found fishing with the cormorant everywhere practised on the lower sections of the Grand Canal and the connecting canals in the Yangtse Delta and throughout South China generally. 
That there is cormorant breeding in Kwei-chou Province may be inferred from a note of E. H. Parker (Up the Yangtse, p. 233, Shanghai, 1899), who observed fishing cormorants in the gorges of the upper Yangtse and remarks, "They are said to come from the wild lands of Yün-nan and Kwei-chou, notably from the Wu-chiang River in the latter province. There is a well-known place on the Se-ch'wan and Yün-nan frontier, called Lao-wa Tan, which perhaps may have some connection with the catching of these birds." E. G. Kemp (The Face of China, 1909, p. 201) gives a colored picture of the Lao-wa Tan river and village, saying that the name means "cormorant rapid."

Cormorant fishing in Yün-nan Province is attested by T'an Ts'ui 楟萃 in his Tien hai yü heng chi 港海虞衡志 (chap. 6, p. 3b, ed. of Wen ying lou yü ti ts'ung shu), published in 1799 . "In the southern part of Tien (Yün-nan) the inhabitants of many mountains and rivers rear cormorants by catching them. Though it cannot be said that 'all families raise black devils' [quoting Tu Fu], they occur in certain places. In the same manner as they rear falcons to seize pheasants and hares, they raise cormorants for the purpose of catching fish. These birds perfectly understand the commands of men and exert themselves for men's benefit. They are also styled 'aquatic old crow.' It happens that several birds unite forces in catching a large fish, some pecking the eyes of the fish, others its fins, others its tail and dorsal fin. When the fish is thus exhausted, they lift it together out of the water, and their master takes the fish. Truly, a clever performance!" See also Yün-nan t'ung chi $k^{\prime}$ ao (chap. 68, p. 23), which in the main cites T'an Ts'ui.

His observation as to several birds seizing a large fish is quite correct and has also been made by several European writers. "And, what is more wonderful still, if one of the cormorants gets hold of a fish of large size, so large that he would have some difficulty in taking it to the boat, some of the others, seeing his dilemma, hasten to his assistance, and with their efforts united capture the animal and haul him off to the boat" (R. Fortune). Harting once saw three cormorants trying to tackle a large eel which one of them had brought up, but from its size and weight could not hold; the other two came to his assistance, and the three worried it like hounds with a fox.

F. Garnier (Voyage d'exploration en Indo-Chine, I, 1873, p. 517) noticed the fishing with cormorants on the lake of Ta-li fu, Yün-nan, saying that the fishermen cast rice on the water as a bait to the 
fish. Prince Henri d'Orléans (From Tonkin to India, 1898, p. 141) observed cormorant fishing on the lake of Ta-li fu, giving a sketch of a boat with eight birds.

The province of Se-ch'wan has been an active center of cormorant breeding and fishing ever since the days of the Sung dynasty. We have seen in the section of Historical Data that the prefecture of $\mathrm{K}^{\prime}$ wei-chou 㠇州府 played an eminent role in this respect during the middle ages. The Se-ch'wan t'ung chi 四川通志 (chap. 74, pp. 21, 28a) gives the same prefecture, as well as Mei chou 盾州, among localities where cormorants are kept. They are likewise used in the districts of Ch'eng-tu and Hwa-yang (成 都䅫志, chap. 3, p. 10; 華陽䅫志, chap. 42, p. 49b).

On the whole, cormorant fishing occurs intensely in central, western, and southern China. The foregoing citations of localities should merely be taken as examples. It is impossible and also unnecessary to give a complete list of such localities. In the north of China keeping of cormorants is comparatively rare, but sporadically it does occur wherever conditions are suitable.

As to Shan-tung, F. von Richthofen (Schantung, 1898, p. 97) limits cormorant fishing to the western part of the province, which is quite natural, as the employment of the bird followed the Grand Canal. John Barrow's (Travels in China, 1804, p. 506) brief remarks refer to Tsi-ning chou.

J. Nieuhoff's (or Neuhof's) account (Gesantschaft der ost-indischen Geselschaft, 1669, p. 134) of cormorant fishing refers to Ningyang 蜜陽 in Yen-chou fu, western Shan-tung. In another passage (p. 353) Nieuhof writes that the bird louwa, as he calls it (the name cormorant was unknown to him), occurs throughout Sina.

Dr. Gudger (I p. 39) has reproduced a photograph taken in 1921 by Mrs. Mary G. Lucas of cormorants ready for fishing on a stream outside of Peking. I have never seen cormorant fishing or heard of it in the environment of Peking or in other places of Chi-li, but Sowerby (p. 72) refers domesticated cormorants to the vicinity of the lakes in Pao-ting fu and to the stretches of water to the west of Tientsin.

That cormorant fishing occurs on the Wei River in Shen-si is known to me only from a photograph published by Clark and Sowerby, "Through Shen-kan," plate XX, which is thus captioned, but no description of it is given.

As has been shown, cormorant fishing is distributed in China over a vast stretch of territory. The cause of this wide distribution lies in the fact that the bird has been truly domesticated and is bred in 
captivity, with the result that hundreds of birds thus bred can be easily transported from one locality to another where there are prospective fishing grounds. In opposition to China, cormorant fishing is restricted in Japan to certain localities and practically to a single fish, the ayu aforementioned. In Japan, the trained cormorants are recruited and always replenished from wild stock, so that no active trade in the birds could develop. The principal and famous old center of cormorant fishing in Japan is the Nagara River 長良川, the town of Gifu 岐阜 being the metropolis of the industry.

Cormorant fishing is further practised on Lake Biwa and in the northern part of Kyūshu in the Naka and Sawara Rivers, in the department of Fukuoka 稫岡䅫, province of Chikugo; and in the Sagami 相摸, Tama 多摩 or 王川 and Ara 荒川 Rivers near Tōkyo, which enter into the Sea of Japan.

A study of the geographical distribution, unfortunately, does not allow us to recognize exactly in what territory of China the cormorant was first domesticated and how it was diffused from this center to other localities. The documents fail us. Certain it is that northern China must be excluded from the places where the domestication might have originated. The lower Yangtse Basin would seem to have been the logical center. I would not lay too much stress on the fact that the majority of Sung authors refer to cormorant fishing in Se-ch'wan; the fact remains that they were not interested in the subject itself, but that they were exercised over the significance of the term wu kwei; and since the latter hailed from Se-ch'wan, the existence of trained cormorants there had to be emphasized. While in this manner we get good evidence for Se-ch'wan, there is no reason to believe that the trained cormorant was monopolized by this province during the Sung period; it must certainly have persisted in the prefecture of $\mathrm{T}^{\prime}$ 'ai-p'ing on the lower Yangtse, where it is reported in the tenth century. Assuming that there the primeval domestication took its origin, it is not difficult to realize how from An-hui and Che-kiang it spread to Fu-kien, Kiang-si, Hu-nan, and Kwang-tung, how another movement sent the domestication up the Yangtse to Se-ch'wan and Yün-nan, and finally how the Imperial Canal promoted its northward migration through Kiang-su, Shantung, and Chi-li. 


\section{RELATION OF JAPANESE TO CHINESE CORMORANT FISHING}

The first problem that confronts us is, What is the relation of Japanese to Chinese cormorant fishing? Did one nation acquire the domestication from the other? Or what was the historical development? The only author who has ever ventilated this question is Dr. Gudger (II p. 8), who argues as follows: "If now the commonly held belief be accepted that Chinese culture and civilization (including the use of the cormorant in fishing) antedated that of Japan, then, since we have dates for the sending of Chinese embassies to Japan, we need not find it difficult to believe that the Japanese learned this method of taking fish from the Chinese, and indeed possibly got their first birds from these embassies." This conclusion, first of all, is based on wrong premises; and, secondly, is a rather sweeping generalization unsupported by any evidence. Gudger did not have the historical side of the question straight. He quotes the notice of the Sui shu indirectly by translating it from Hervey-SaintDenys' rendering of Ma Twan-lin's Wen hien t'ung $k^{\prime} a 0$, and is thus led to the belief that it refers to the thirteenth (instead of the sixth or seventh) century. Ma Twan-lin's work, of course, has no independent value and presents merely a compilation of older sources; the quotation given by Dr. Gudger is merely copied from the account of Japan contained in the Sui Annals. As shown above, this is the earliest extant reference to cormorant fishing in the world, and is much earlier than any Chinese references to the practice in China. The first unmistakable notice of cormorant training in China is not older than the tenth century, so that according to our Chinese documentary evidence the use of the bird in Japan antedates that in China by at least three centuries, while according to Japanese sources it is even much older. For this reason no serious historian will rush at the conclusion that the Japanese have simply adopted the domestication from the Chinese, or will indulge in such comfortable speculations as the one that the Japanese possibly got their first birds from Chinese embassies. If this had been the case, Japanese writers would have been sincere enough to admit it. Whenever the Japanese received cultural elements from China or Korea, they placed such indebtedness on record. We have no right to conclude that because much of ancient Japanese culture is derived from China, 
everything Japanese must have radiated from the same center; this has to be proved for each and every case, and we have to be mindful of the fact that there are numerous Japanese cultural traits which cannot be laid at the threshold of China. L. Reinhardt (Kulturgeschichte der Nutztiere, 1912, p. 403), without giving any reason, alleges that the Japanese learned the fishing with cormorants from the Chinese.

Let us consider the opposite possibility that the Chinese might be indebted to Japan for the trained cormorant. E. H. Parker, in translating Ma Twan-lin's account of Japan (Transactions As. Soc. of Japan, XXII, 1894, p. 44), comments on the cormorant passage, "It would thus seem that the Chinese owe at least one idea to the Japanese." The Chinese knew of this Japanese fishing method in the beginning of the seventh century, and the fact was recorded in the official dynastic annals. The records of foreign countries contained in the Sui shu, as well as the biographical portion, were completed in A.D. 636 . It would not be impossible that a Chinese official who read this notice might have conceived the idea of inducing his compatriots to try the same experiment; but, if an official had taken the initiative in this matter, some official record of this event would surely have been preserved. And then we should expect to see this experiment carried out soon afterwards, say, in the beginning of the T'ang period; yet we face this long gap of nearly three centuries between the Sui and the Wu-tai periods which cannot be bridged over. The possibility that the Japanese account of the Sui shu or Pei shi should have struck the eyes of a fisherman of An-hui, Chekiang, or Se-ch'wan appears to me so remote that it does not merit a discussion.

The plain fact remains that Chinese sources do not admit any indebtedness to Japan in matters of cormorant fishing, in the same manner as the Japanese on their part do not credit it to the Chinese. And this fact, in my opinion, carries weight. I have already insisted on Japanese honesty, and I plead the same degree of honesty for the Chinese. Every one familiar with the history of Chinese civilization knows only too well that the Chinese have always been frank and upright in acknowledging foreign loans. To us trained in scientific thought the domestication of the cormorant appears a significant affair; and, as pointed out, it is a unique phenomenon in the history of the world. To the Japanese and Chinese, however, who alone of all peoples accomplished the permanent training of the bird, it is something insignificant over which they never made any fuss. These two nations were always distinguished for modesty, reserve, lack of 
conceit and ego worship. Neither preserved the name of the first fisherman or men who did the deed. It was too trifling a matter. But if the Greeks or Romans had accomplished it, what pride would swell the chests of our classicists! Of course, the Greeks would have handed down the name of the "inventor" with a romantic story of how his genius was inspired by the gods, and every school boy in our midst would be obliged to learn it by heart. As matters stand now, he is spared this thrilling or sad experience, and things peculiarly Japanese and Chinese do not bother our public. The thirteenth edition of the Encyclopaedia Britannica devotes an entire column to the cormorant with a lengthy story of its training in Europe, but maintains cold silence about its domestication in Japan and China! In the fourteenth and last edition the article in question is curtailed to a half column, and it is said, "The practice is nearly obsolete in Europe, though still common in China." And this is all.

As the evidence stands, there is but one conclusion admissible, and this is that the domestication of the cormorant and everything connected therewith was independently achieved in China and Japan. This conclusion is corroborated by many facts which lie in the domestication itself. The principal facts are as follows:

The method of using and treating the cormorant in Japan is fundamentally and radically different from that of China. Here the Latin saying "si duo idem faciunt, idem non est" holds good. What the Japanese practise may be briefly defined under the name of the harness or team method. A cord or rein of spruce fiber, about twelve feet long, is attached to the body of each bird, and the master lowers the birds one by one, altogether a team of twelve, into the stream and gathers all reins in his left hand, manipulating the various lines thereafter with his right hand, as occasion requires, to keep them free of tangles. This method is absolutely unknown anywhere in China. In China, the cormorant has reached a perfect stage of domestication, is reared in captivity, and is the born slave of his master. Nothing like this is at present done in Japan, where the cormorants pressed into service are all caught from wild stock on the coast of the Owari Gulf and immediately receive their training. The Japanese method in all its various details is as different from the Chinese as both Japanese and Chinese methods are at variance with that formerly adopted in Europe. What these methods are will be more fully discussed in the following chapter. The point to be made here is that in view of these principal differences Chinese and Japanese utilization of the cormorant cannot have a common basis of origin. The two are entirely distinct. The only point in 
common to the two civilizations is that the cormorant is used by man for the purpose of catching fish; but this is all, and here the coincidence comes to an end. The discrepancies outbalance in weight the outward similarity. Different causes, different methods and technique have merely yielded a similar result.

Another observation remains to be made. It is a significant fact that cormorant fishing was never practised in Korea and that it is unknown there at present (I speak advisedly, as I had occasion to interrogate Korean students on this point). Accordingly, cormorant fishing does not belong to that series of culture elements which spread from China to Korea and were further transmitted from Korea to Japan. In fact, the Chinese cormorant domestication did not spread at all; it was not communicated to any of those nations which came under the spell of Chinese civilization. The aboriginal tribes inhabiting western and southern China did not adopt it; neither did the Annamese or any other peoples of Indo-China or the Siamese, Burmese, or Malayans. The domestication of the cormorant and the peculiar method of raising, training, and using the bird have remained a purely and typically Chinese affair. And this method did not spread to Japan. Japan has evolved a method of her own and peculiarly herself without the aid of outward influences.

The question of a possible mutual stimulus, that may be raised, dwindles into insignificance and is wholly immaterial, as compared with the basic processes. If it is a question of priority and precedence in originality, the balance of the evidence certainly favors the Japanese. 


\section{THE PROCESS OF DOMESTICATION}

The only scholar who has treated of the cormorant as a domestication, unfortunately too briefly, is Eduard Hahn (Die Haustiere, 1896, pp. 347-350). No other book dealing seriously with domesticated animals - and there are many of these-mentions the cormorant. Hahn points out that the cormorant as a domesticated animal is an achievement of Chinese civilization, which shows the patience and intelligence of the Chinese at their best. He refers to Friar Odoric, Armand David, and R. Fortune. It was vaguely known to him that fishing with cormorants is practised in Japan, and he offers a curious misunderstanding of a passage in Journal asiatique (1871, p. 403), "If it be correct that the mythical Matwan-lin is Japan, this method must go back to very ancient times, as far back as the sixth century A.D." L. Reinhardt, in his popular book, "Kulturgeschichte der Nutztiere" (1912, pp. 400-403), gives a few notes on the life of the wild bird, copies the historical information of Hahn (without acknowledgment and adding some errors of his own), and says very little about the domestication itself.

The wild cormorant is not difficult to tame. The only statement to the contrary I have found is made by L. Reinhardt (op. cit., p. 403), who writes, "As the excellent ornithologist Naumann with good reason designates the cormorant as difficult to tame and fond of biting, the great patience and endurance of the Chinese in making it a domestic animal must be the more acknowledged." Naumann may have been a good ornithologist, but has never attempted to train a cormorant. Those who did venture to dissent from him.

Harting (p. 438), who had much experience in training cormorants, states that "cormorants are by no means difficult to train, and do not require half the care and attention which has to be bestowed upon hawks for example." Pichot (p. 27) writes in the same spirit. "This web-footed marine bird is very easily tamed. His heart is very near to his stomach, and one may be reached by way of the other. As I was engaged in falconry, I was naturally led to practising cormorant fishing. This is a delightful sport and the easier, as the cormorant becomes rapidly familiar; if you feed him out of your hand, you will have trouble to prevent him from following you everywhere, ascending the stairs behind you, perching on your furniture, and leaving on all pieces incontestable traces of his rapid and abundant digestion." 
In China, the cormorant has attained the stage of a complete and perfect domestication, the birds propagating and being reared in captivity. It is said by Sowerby (p. 73) that the domestic stocks are replenished from time to time by the capture of wild birds or by robbing the latter's nests; it is very sensible, of course, to refresh the blood of a domestic species occasionally by interbreeding with a wild congener, but I believe this is but seldom done. The early travelers to China were merely content to record their surface observations of cormorant fishing without inquiring into the life and habits of the bird. Nieuhoff was the only one who possessed enough intelligence to ask the question whether the birds also propagated and bred many young, and was given the reply that "this happens, but very slowly and little." (Dr. Gudger [I p. 12] cites Nieuhoff in Ogilby's English translation of 1669 , which in the cormorant section is inaccurate and deficient.)

A statement concerning the use of domesticated birds is also found in a Chinese source. The Hu-nan fang wu chi 湖南方物志 ("Record of the Local Products of Hu-nan Province"), written in 1818 by Ki Chung-liang 瀷仲良 and Tsiang Siang-wei 蔣裹維 (chap. 7, p. 14; edition before me printed in 1864) cites from the San ch'ang wu chai Ch'ang shwo 三長物弯長說 the following: “In the south the cormorants are all attached to the fishermen's houses, and are fed and reared by them. I have never heard that birds born

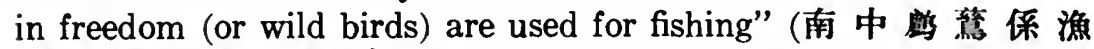
家繁表未聞有野生者). The date of the book San ch'ang, etc., is not directly known to me, but as farther on Li Shi-chen's Pen ts'ao kang mu is quoted in it, it must be a product of the seventeenth or eighteenth century; the title of the book is $C h^{6}$ ang shwo, and it was published by the San ch'ang wu Studio which issued also a ts'ung shu.

The effect of the domestication is shown in the complete submission and subordination of the birds, who become as docile and obedient as dogs, knowing their master and his boat and understanding his commands perfectly well, and in their outward appearance they display variation in color, a marked characteristic of all domestic breeds. Sowerby (p. 72) observed in Chi-li many pied or even pure white individuals.

The females lay yearly from three to nine eggs in the first and eighth month. The eggs are green in color and the size of a duck's egg; what is called the white of the egg is light greenish; the eggs are never consumed. The eggs of the first month are the only ones retained for hatching, for the reason that the young birds will grow 
up in the spring; if those of the eighth month were hatched, the young, who are extremely sensitive to cold weather, it is feared, would not live through the winter. The eggs are always hatched by hens, not by the cormorant mother. The only author who gives a different account is Dabry de Thiersant, who writes that "the cormorants prepare in a spot retired and dark a nest of straw, on which the female lays her eggs which she herself covers all the time." I have but little confidence in this statement, in view of the fact that the author shows himself rather uncritical and credulous in his notes on the cormorant; for instance, when he asserts that on the tenth day after birth the fledglings are taken by the trainer out on his boat and seek their places on the common perch; while the training, in fact, begins only two months from the date of birth.

The fact that the eggs are given to hens to hatch is attributed by several authors to the female cormorants being bad mothers (Fauvel, p. 230). "Curiously enough the mothers are so careless that they cannot be trusted to rear their own young" (Gordon-Cumming in Dyer Ball, p. 182). This comment savors of Chinese mentality, being made in response to a question, and is either really believed by the breeder or is just elicited to satisfy the curiosity of an importune inquirer. This explanation, of course, is absurd, for "the young of the wild species are assiduously fed and cared for by the parents" (Sowerby); and how with this alleged lack of maternal affection could the species have spread over the entire world? The female kept in captivity lacks her nest in high trees and the natural conditions of her life, and this rather is the reason why she declines to incubate the eggs. Moreover, experience has taught the breeders that safer and faster results are attained from hens than from female cormorants.

The fledglings come out of the egg after a month's incubation. They cannot stand on their legs, and are very sensitive to cold. They are transferred to cotton-stuffed baskets which are kept in a warm room. The young birds are enveloped in cotton wool and fed with small morsels of bean-curd (tou-fu) and pellets of raw fish, preferably eel, if procurable. Cormorants are inordinately fond of eels and prefer them to all other fish; where eels are plentiful they will even catch nothing else. Fortune was given the information that for five days the young are fed with eels' blood and that after five days they can be fed with eels' flesh chopped fine. Dabry de Thiersant denies that this is done in the central provinces, and states that during seven days the young receive three times a day finely minced meat which they prefer to any other food; afterwards small fish are added to the meat. There is no doubt that in matters 
of feeding and training a good many local variations exist. Lean and weak birds are fed on dogs' flesh (Ning-hua hien chi 管化䅫志, chap. 2, p. 128). "After the tenth month the cormorants are given dog's flesh which will keep their bodies warm and protect them from the cold; even when breaking through the ice and plunging into the water, they will not die from a chill" (Pen ts'ao kang mu shi $i$, chap. 9, p. 7b).

Under the heading "Method of rearing cormorants," Fang I-chi 方以智, in his Wu li siao shi 物 理 小識 (chap. 10, p. 5), gives the following brief notes: "For a period of six months the (young) cormorants are susceptible to cold. Their keepers wrap them in refuse cotton and feed them with pepper. In autumn and winter the birds are turned loose into the water to catch fish. Those incubated in the summer are so strong that they can peck up the eyeballs of large fish." If pepper is given the young birds, it must be mixed, of course, with some food, which Fang I-chi forgets to mention, and may act as a sort of tonic.

At the end of a month feathers begin to cover the down, and the quantity of fish is increased for their diet, while the proportion of bean-curd is reduced. After the second month the birds have doubled their size, and are fit for the market, a female being half as much in price as a male. This difference in price is due to the superior strength of the male who is able to capture larger fish.

When the nursery days are over, the schooling of the birds begins at once, and they are turned over to a professional trainer. Their wings are clipped to prevent their flying away. The first lesson is as follows. A string is tied to one of the bird's legs, the other end of the string being fastened to a stake set in the bank of the pond or canal. The bird is driven into the water, the trainer whistling a peculiar call and, if necessary, enforcing obedience by the persuasive strokes of a bamboo, the great educational means of China. Small live fish are thrown to the bird who will pounce upon them greedily, as he was previously kept on a reduced diet. He, is now called back by a different whistle signal and, to make him understand, is first pulled back by means of the string or line until he has learned to comprehend the call and to obey it spontaneously. This procedure is repeated daily for about a month till the bird is accustomed to his master's voice and commands.

The second lesson is given in a boat along the same line as previously, and lasts four or five weeks according to the bird's intelligence.

When the young birds are accompanied by older well-trained birds, which is usually done, the time of instruction is shortened 
considerably, as they will quickly learn from their elders. At the end of this period they are relieved of the leash or line. Birds not properly trained by that time are regarded as stupid and hopeless. A period of seven or eight months may be considered sufficient to turn him into an expert fisher.

There is a good deal of individual character in the birds. Some are intelligent, alive, and alert; others are dull, lazy, and sulky. Some are more expert at diving and catching than others. European writers have described the cormorant as "solemn, weird, uncanny"; but such words are elicited by impressions of our mind, and are not objective characteristics of the bird. What is more important is that each bird possesses enough individual characteristics to enable his master to recognize him among a flock of other birds working in the water; and vice versa, the birds are endowed with sufficient intelligence to know their master and their boat; they always occupy the same place assigned to them in the boat. Many fishermen name their birds, and will always call them by their names.

"These birds differ much in their tempers, some being most spiteful and savage, as well as shy and disobedient in the field, whilst others are just the reverse. They are very sagacious, knowing the places where they have caught fish and are likely to meet with them again, etc. They are also capable of great affection. Honest 'Isaac Walton' was particularly fond of his master and, singularly enough, he would not allow any one else to approach without showing fight. When angry, the cry somewhat resembles the gobble of a turkey, and when pleased, it is a loud guttural sound, like "haw, haw!" (Freeman and Salvin, Falconry, p. 331).

The domesticated cormorants of China live in basket-like cages, or in the summer are also left in the open where they are tied to their perches by means of a leather thong fastened to one of their legs.

The fisherman who uses the birds is not necessarily the breeder. There are special establishments which make it their business to breed the birds and to sell them or lease them to the fishermen. Fortune mentions such a large establishment, which he visited in 1848, thirty or forty miles from Shanghai and between that town and Chapu, where a pair was then sold at from six to eight dollars. The tenants usually repay the owner of the birds with a certain quantity of fish. Under this system the birds are worked as hard as possible, for the fisherman's sole interest is in catching as large a booty as possible in order to gain a surplus for himself in excess to what he owes to his landlord. Under these circumstances the friendly and sympathetic relations that exist between man and his 
domestic animals must be completely lost. The wholesale breeding of birds, however, has one advantage that they can be distributed and sold in the entire country.

The earlier writers on China represented cormorant fishing as a sort of royal monopoly. $R$. Willes (see p. 245) has a fantastic account of the king of China possessing a good store of barges full of sea-crows allowed a monthly provision of rice; these barges the king bestows upon his greatest magistrates. Juan Gonzalez de Mendoza has a similar story, and Nieuhoff has the fishermen pay an annual tax to the emperor for the use of the birds. With reference to Lord Macartney, who stated that exorbitant taxes had to be paid to the emperor for the permission to use cormorants, Fauvel remarks that he never heard of such in Che-kiang and that they probably existed nowhere in his time. Of course, the cormorant fishermen, like every one else, paid an annual tax, but these taxes never were excessive, nor has a government monopoly on cormorants ever prevailed, nor has the government to all appearances ever taken an interest in the whole business. It is known to every one who was in the China of the Manchu dynasty that the people were in the habit of complaining and sobbing to foreign visitors about high taxation, oppression, and extortion, while in fact they were the most lightly taxed people in the world, comparatively speaking. In Chinese sources I have found nothing alluding to a cormorant monopoly or special taxation. The only item I have found is as follows:

In the Gazetteer of Ning-hua 寧化䅫志 (chap. 2, p. 128), in the prefecture of T'ing-chou, Fu-kien, it is stated, "At present the inhabitants of Yen and Kien 延建人 (Yen-p'ing fu and Kien-ning $\mathrm{fu}$, who raise these birds, pay their taxes to the officials in rice * 于 官."

Authors like Fortune and Fauvel have also given price quotations for the birds, which can hardly claim any validity at present. I mention only that the Ning-hua hien chi (chap. 2, p. 128) gives the price of a single bird as ten taels (ounces of silver), and this may be regarded as an average value.

Most writers who have described cormorant fishing, although their accounts are incomplete and deficient, do not fail to mention the ring or strap around the bird's neck, and do not get tired of repeating the worn-out statement that this is done to prevent him from swallowing the fish which he catches. Friar Odoric (Yule, Cathay, new ed., II, p. 190) is the first of European travelers who noted that the fisherman tied a cord round the birds' necks that they might not be able to swallow the fish which they caught. True 
it is Chinese authors make the same statement. Several have been quoted to this effect (p. 224), and another may be added here. "Those who raise the cormorant tie a cord around its neck, so that small fishes can pass its throat, while big fishes can not; from time to time the fishermen call the bird and take the fish away from it; and then they send it out again" (Yung-ch'un chou chi 永春州志, chap. 7, p. 22; the same in Ning-hua hien chi, chap. 2, p. 127; both localities are in Fu-kien).

The fact itself is correct, but is not logically expressed. That the cormorant is prevented from swallowing a large fish is the effect of the ring or strap, but not the cause of it, which is quite different. The ring is the symbol of the cormorant's bondage, and was the original expedient that brought its domestication about. It takes the place of the dog's neck-collar, the horse's bit, the water-buffalo's nose-ring, the falcon's leash and hood. In order to govern and keep a cormorant, man required some means of grasping and holding him, and a cord of hemp slung around his neck and terminating in a line which man could seize was the means he devised. Man's first thought in training the bird was to hold him in check, to bridle him, to direct him; he did not think, at first, of preventing the bird from swallowing large fish; this resulted as a secondary effect from the use of the strap or ring.

The ring is called chüan 圈 (Ma-kia-hiang t'ing chi 馬家巷廳志, chap. 12, p. 11); in the Sui shu, as pointed out above (p. 212), hwan.

Great care must be exercised in placing the cord or strap around the bird's neck; it must be fastened in such a way that it will not slip farther down upon his neck, as this would be apt to choke him.

Different materials are used for the ring in various localities; straw, hemp, bast, tow, bamboo (Kwang-tung), rattan, and even iron (Maffei and Nieuhoff) are reported. The use of iron is unnecessary, even foolish, as its weight will hamper the bird's free movements.

That the neck-collar is merely a stepping-stone in the gradual development of the domestication becomes clear from the fact that in the last and highest stage of development the neck-collar is simply discarded, especially in Che-kiang. At this stage of the game the birds are disciplined to such a degree of perfection that they fish in unrestrained and absolute freedom. A well-trained cormorant, while on duty, will not swallow any fish whether large or small; he knows his business and his lord.

G. Staunton (Account of an Embassy to the Emperor of China, 1797, II, p. 388), for instance, reports that "the birds appeared to be so well trained, that it did not require either ring or cord about 
their throats to prevent them from swallowing any portion of their prey." His observations were made on the Imperial Canal near Hang-chou. Milne (Life in China, 1857, p. 307) writes that he could find neither ring nor cord about the necks of any of them to prevent the swallowing of fish.

De Guignes (Voyages à Peking, I, pp. 271, 289) states expressly that in Kwang-tung Province, where he noticed cormorant fishing in three different places (in 1794), the birds were free and appeared well tamed; "they did not have, as P. du Halde says, a collar around their necks."

What Friar Odoric describes (Yule, Cathay, II, p. 190) is also a free method of fishing which indicates a highly developed stage in the evolution of domestication, though of a somewhat lower degree than the preceding one. The water-fowl were let loose without being driven, and straightway began to dive, catching great numbers of fish and putting these of their own accord into the baskets, so that before long all the three baskets were full. Of course, as mentioned previously, Odoric's birds were equipped with the neck-strap; and when their task was finished, they were tied to perches in the boat.

In some parts of the country the fishermen haul the bird with his catch out of the water in a dip-net, and methods of managing the bird vary according to locality. For instance, at Tsi-ning chou and probably in other places too, the fisherman who commands a flock of ten or twelve birds will not rush all of them into the water at once, but will allow only one or two of them to dive at a time; and when he perceives that they are fatigued, he will take them in and feed them and then dispatch another pair into the water. This humane method has the advantage that it will give the poor workers a good chance for rest. On the Min River in Se-ch'wan cormorants, after diving, are brought up to the surface in baskets of much the same shape as the birds (E. G. Kemp, The Face of China, 1909, p. 180).

Some of these varying practices, particularly those bearing on minor details, may simply be due to local variations of custom; but in the main, the basic differences are an index of the various stages through which the development of the domestication has run. It is clear that the more the bird's movements are restricted, the more restraint is imposed upon him, the older this stage of development must be. It was gradually recognized that the laws deemed necessary for his enslavement need not be too rigidly enforced, that the creature was attached to his master and would not forsake him, that barriers could be slowly removed and a greater amount of liberty be restored to him. In this point the Chinese have manifested admirable 
wisdom, and have advanced far beyond the Japanese. This indeed is the goal for which all cormorant domestication must strivegranting the bird a maximum degree of freedom. This makes a happy cormorant and a more successful and therefore happier fisherman.

Another implement indispensable to the cormorant trainer and fisherman is a long bamboo pole, which serves a twofold purposepropelling the raft or boat tenanted by the fisherman with the heavier end of the pole and directing and controlling the movements of the birds with the other. He uses the pole as the conductor of an orchestra does his baton. When the theatre of action is reached, he signals to the birds to dive by beating the water with the pole. When a bird fails to attend to his business, a blow of the bamboo on the water near where the bird floats accompanied by an angry shouting, is sufficient to remind him of his duty. Whenever a bird gets tired, or when his gullet is filled with rich booty, the pole is stretched forth so that he may jump and perch on it, and be lifted into the boat. On the same bamboo pole the birds are carried from their home to the water's edge and back home when their task is done (compare Plate XIII).

The methods of fishing with cormorants have frequently been described and are beyond the scope of this study which is concerned with the cormorant as a domestication; but I wish to mention one point, as it has not been brought out by previous authors. There are two principal methods of fishing-the solitary one and the method of group fishing. A man single-handed, especially on a raft, is able to manage three or four cormorants and to attend to the whole business (see Plates XV-XVI); a variation of this is duet fishing when two men join in dividing labors, one steering and propelling the boat, the other tending the birds and the fish caught by them. Rafts are chiefly used in the southern provinces. Boats are either single, or two of them are placed side by side and connected by a plank; the latter are more stable (illustration in Korrigan, p. 42). The raft owners usually operate with from two to four birds; the boat masters, with ten or twelve. In group fishing a fishermen's gild or association gets together and makes common cause. A fleet of small boats moves into action and spreads out in a line or crescent formation, setting the frightened fish moving and driving the birds in front. As each fisherman knows his own birds and as each bird knows his boat and his place on it, everything proceeds in orderly fashion. The concerted action in this manoeuvring naturally insures a larger haul of fish. The solitary method assuredly is older than the 
group or community method, and is the one pointed out in our earliest Chinese source, the $T s^{\prime} i n g ~ i l u$, which advisedly refers to "a single man" (above, p. 221). The first mention of community fishing occurs in R. Willes' Reports of the Province of China (about 1565), based on the data of Portuguese, chiefly Galeotto Pereira (Hakluyt, Glasgow ed., II, p. 327). Here it is said (I modernize the old English spelling), "At the hour appointed to fish, all the barges are brought together in a circle, where the river is shallow, and the crows tied together under the wings are let leap down into the water, some under, some above, worth looking upon; each one as he has filled his bag, goes to his own barge and empties it, which done he returns to fish again. ... There were in that city where I was, twenty barges at the least of these aforesaid crows."

From what has been said about the present-day training of cormorants, it is not difficult to imagine what the steps in the primeval process of the domestication have been during the tenth century. A wild young cormorant was ensnared, and the Chinese have always been skilful bird-catchers. A cage with a perch, a cord and a leash or line, a bamboo pole were all the paraphernalia required. A noose was tied around the bird's neck, and along a line he was immediately dispatched into the water. The first man who did it merits greater admiration for the originality of his idea than for what he accomplished, while the bird as the natural fish-hunter is deserving of greater credit for the achievement. At the outset it is difficult to realize what keeps the enslaved cormorant in bondage, or why he continues hard labor for an employer who has so little to offer him in return. The service of domesticated animals is based on a silent pact which gives them advantages not enjoyed by their wild congeners: proper shelter, protection from rapacious enemies, adequate food, and assurance of a constant and regular food supply. The cormorant to some extent suffers from what the modern Chinese would call an "unequal treaty." He is hardly fed by man, but looks out for his own meals, catching his own fish. In some parts of China he is given a morsel to eat after every catch, and some fishermen even feed their birds with their own hands, stroking their necks to facilitate the downward movement of the food, which the birds are said to like very much. They are also fed with morsels of bean-curd, but this alone can hardly be a sufficient attraction for the bird to remain in his state of socage. He has no natural enemies, as chickens and pigeons have, from whom he would need protection. His quarters are by no means palatial or sumptuous, and there is but little sentimentality in a fisherman's heart. Even granted that he treats his 
birds well in his own interest, the cormorant's psychology is not perfectly clear and requires further elucidation. I have never heard of a cormorant attempting to break loose in order to gain his liberty, and with his wings clipped and his spirit broken it is questionable how far he would get; probably he would be pursued and soon captured by his owner. Born and raised in captivity, he is ignorant of the sweetness of liberty and looks upon slavery as his natural lot.

While the domestication of the cormorant has passed through several successive stages and has improved by degrees, it is not necessary to imagine that the primeval or initiatory process was a superhuman task which required a long span of time. I have therefore suggested that in accordance with the present state of our knowledge the beginnings of the domestication in China should not be dated farther back than the tenth century A.D.

In its natural state the cormorant is said to live twenty to twenty-five years. It is an interesting fact that in Japan the captured and trained birds reach a much higher age than the domesticated ones of China. According to Ikenoya, the Japanese birds will live to the age of twelve. Palmer, as quoted by Chamberlain, estimates that they work well up to fifteen, often up to nineteen or twenty years of age. According to Kuroda, birds from four to eight years old are the best; beyond this age they begin to slow down in their work, but they can be employed up to about fifteen years of age.

According to Jametel, the cormorants of China begin to lose their plumage from their fourth year, and they usually die before reaching the age of six years. Fauvel (p. 233) states that a good cormorant can serve during five years, but at the lapse of this period begins to lose its feathers and will die soon. Dabry de Thiersant, however, was informed that the birds are serviceable up to the age of ten years. Whatever the exact facts on either side may be, there is no doubt that the average is much higher in Japan than in China. And the reason for this is not far to seek. The Japanese birds are kept busy only a five months' season and rest during the winter, while the Chinese birds are worked and overworked the whole year round, except during extreme frost in the winter. The Chinese have not yet learned that domestic animals also need a vacation and time for rest and play and that this concession will prolong their lives and intensify their ability to work. There is no doubt also that the Japanese treat and nurse their birds better than the Chinese. In the summer, the cormorant quarters in Japan are even surrounded with mosquito nets. Lack of cleanliness in their cages must necessarily breed disease and doom many birds in China to a premature death. 
But aside from this, the Chinese method of domestication is infinitely superior and preferable to the Japanese method of catching young birds and training them. They are caught on their roosting places around Shinoshima in the province of Owari. Their wings are clipped, and they are sent blindfolded to Gifu. At first they are very vicious, and are kept tied up. They are daily taken out at noon, under the leash, on the river and allowed to dive, catch, and swallow from one to two pounds of fish. After about fifteen days they are taught to catch and disgorge fish.

At Gifu a cord is attached to the bird's foot and passes under its belly up to its neck where it connects with the ring. Twelve birds form a team, and their cords are fastened to a single line directed by one master. In this manner the cormorants are kept close to the boat and hampered in their free movements. Pichot (p. 32), in criticizing this method, remarks that the true sport consists in having the cormorant work with liberty without any other means of restraint than the leather ring around his neck. I would go a step farther and say that, as demonstrated by the example of Chinese fishermen, even the ring can be dispensed with and that a well-trained cormorant may be given the "freedom of the seas." It might be advisable for the Japanese to send a commission of experts to China for a thorough study of the Chinese system of cormorant breeding with a view to apply it at home, or at least to improve the domestic system. On the other hand, I am sure, Japanese cormorant experts could teach the Chinese a great deal in the proper care of their birds.

The complex and cumbrous apparatus set in motion by the Japanese is unconsciously inspired by the fear lest the captured bird might escape, and he is fettered and closely watched every minute. Too much unnecessary fuss is made about the whole business, and too many fads and frills are connected with it. In the fishing method followed by the Japanese the birds are unnecessarily excited, and their agitation when in the water is increased by the burning sparks which fall into the water from the braziers or cressets on the boat intended to illuminate the nightly scene. The weird light of lanterns, the noise from music and songs on the boats of the pleasure-seekers make the birds still more nervous.

The Japanese procedure in fishing with harnessed cormorant teams has the one advantage that the keeper has absolute control over each member of his team and can pull him out of the water from his particular line instantaneously he has caught some fish. The Chinaman may lose some time in giving commands or reprimanding or punishing lazy or recalcitrant birds, but he is more 
humane and more sportsmanlike in allowing his birds some freedom of action; and freedom, after all, is what makes good sport. The Japanese method, although in its outward appearance a sport, is, in fact, not a sport, at least so at the present time. I am inclined to think that it was different in ancient and mediaeval Japan when the cormorant was still regarded as a sacred bird. It was this sacred, mythological character of the bird which prompted the ancient Japanese to keep it in captivity, and, I am disposed to believe, to domesticate it, although I cannot produce any documentary evidence to this effect. In the modern Japanese and European sources I have been able to consult nothing is said about the birds propagating in captivity or the breeding of birds born in captivity; I should be very grateful for any information on this point, as it is an important matter for the history of domestications.

In opposition to Japan cormorant fishing in China is carried on during the day. This is reported alike by all observers. Sowerby (p. 73), however, asserts that "sometimes and in some parts of China the fishing is done at night, when great flares are carried on the boats, which serve to attract the fish and also to help the birds to see them." It would be interesting to have more specific information on this point, especially as to the localities where it is done and as to the methods applied.

In Japan, in opposition to China, cormorant fishing is usually carried on during the night. In China it is an industry from which fishermen gain a livelihood, while in Japan it has rather the character of a sport connected with pleasure parties and spectacular festivals for the entertainment of illustrious visitors and ordinary sightseers. This, however, to all appearances, is a modern development which does not hold good for ancient and mediaeval Japan. This recent sporting tendency may be largely due to two imperial visits at Gifu in 1878 and 1880.

Where cormorant fishing is a commercial enterprise in Japan, it is also carried on in daytime only, in one locality both night and day.

Another difference between China and Japan is that Japanese cormorant fishing is practically restricted to the ayu (above, p. 213), while the Chinese without discrimination take any fish the cormorant is able to hunt. 


\section{EGRET TAMING}

A question that remains to be answered is whether there is any relation between otter fishing, as still practised in the upper Yangtse Basin, and cormorant fishing. It would seem so at the surface, judging from a remark of Sung $\mathrm{K}$ ' $\mathrm{i}$ 尔侕 (A.D. 998-1061), who in his

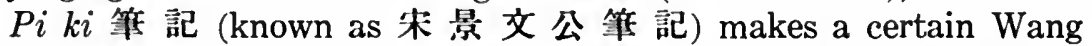
Tse-huan王子幻 say that he saw with his own eyes at Yung-chou (in Hu-nan) tame otters kept for fishing in the place of (or, as

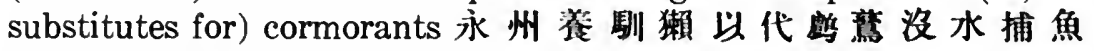
and that these daily caught about ten catties of fish, enough to supply the want of a family. Wang Tse-huan was apparently familiar with cormorant fishing, while the sight of otter fishing was a novel experience to him. It cannot be said, however, with any regard to historical truth that the otter replaced the cormorant in certain parts of the country; for otter fishing was practised at an earlier date than cormorant fishing and was known under the $T$ 'ang. Translations of two passages to this effect from $T^{\prime}$ 'ang authors were transmitted by me to Dr. Gudger, who published them in his article Fishing with the Otter (pp. 198-199). As cormorant fishing was in all probability inaugurated in the Lower Yangtse Valley in the beginning of the tenth century, the two events are distinct as to space and time, and it is hardly necessary to assume an interrelation of the two. It may be, of course, that news of otter fishing on the upper Yangtse reached fishermen in the lower course of the river and might have suggested to them a similar idea which may have set them to thinking about the cormorant. For the rest, the two events are entirely different. The cormorant was gradually brought into a state of domestication, while the otter could merely be tamed, and has always remained in the feral state.

The egret ( $l u$ 督, Ardea egretta) was also kept in captivity, although it is not stated for which purpose. The earliest notice to this effect I have been able to find occurs in the Mao shi ts'ao mu niao shou

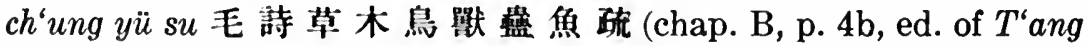
Sung ts'ung shu), where it is said, "At present the people of Wu also raise egrets" (今吳人亦琵琵). The authorship of this work is ascribed to Lu Ki 陸㙨 (A.D. 260 or 261-303), although my edition of the T'ang Sung ts'ung shu makes him "T'ang"; but as Legge 
(Classics, IV, p. 178) says that "the original work was lost and that now current was compiled, it is not known when or by whom, mainly from K'ung Ying-ta's constant quotation from it," it is difficult to date the above passage. The Wu lei siang kan chi 物類相感志, ascribed to Su Shi (A.D. 1036-1101), says that "the heron is kept by men in ponds and becomes as tame as domestic fowl; whenever the day Pai-lu 白露 (8th of September) appears, the herons fly away and are gone." This evidently refers to the southward migration of the birds. The same information is given in the $P^{\prime} i$ ya 埤 雅 by Lu Tien 陸 佃 (A.D. 1042-1102), who writes that “the people of the present time raise white herons intensely and that there are birds quite tame and docile; when they have left on the day Pai-lu, they cannot be kept again." The Hwa king 花 鏡, written by Ch'en Hao-tse 陳哚子 in 1688 (chap. 6, p. 4b), says that many people keep these birds in ponds and pools.

Li Fang 李昉 (A.D. 924-995), compiler of the T'ai p'ing yü lan, is said to have raised five herons whom he called "cloud guests" (yün ko 雲客), according to the Ts'e lin hai ts'o 詞林海錯.

The Gazetteer of Shao-hing 䂙興 府志 (chap. 11, p. 31) gives the following information: "The egret is snow-white in color, and on its crest has a silk-like bunch over a foot long; when the bird desires to catch fish, it droops this feather-bunch. Many people living on the banks of rivers north of the mountains keep the egret in their houses, and the birds become so tame that they do not fly away; only during the day Pai $\mathrm{Lu}$ 白露 (8th of September) is it necessary to cage the birds for the entire day so that they do not escape."

If this information be correct (and it should be verified in the locality), egret taming may bear some relation to cormorant training. It is a curious coincidence that the employment of the heron in the service of man begins about the same time as, or a little earlier than, cormorant training, but it seems never to have reached a great practical importance. 


\section{ICONOGRAPHY}

The oldest representation of a cormorant known to me is a carving in jade of the Chou period in Field Museum, Chicago. Illustrated in Laufer, Archaic Chinese Jades, 1927, plate XXVI, fig. 7 , and as a vignette on page 205 of this article.

It is singular that cormorant fishing has not inspired any great Chinese artist. To be sure, there are many drawings and pictures of the subject of Ming and Ts'ing periods, but all these are mechanical productions of small or no artistic value. I feel almost confident in saying that no T'ang or Sung artist has ever painted a cormorant. The Süan ho hwa $p^{c} u$ 宣和書譜 enumerates many pictures of herons, even herons engaged in fishing, for instance, by Hwang Kü-ts'ai, but not a single cormorant painting.

Fishing with cormorants is depicted in a Chinese painting attributed to the Ming period (weak as a painting and teaching but little about the method of fishing), reproduced in O. Sirén, Chinese Paintings in American Collections, plate 138.

A finger-painting by $\mathrm{Kao} \mathrm{K}^{\prime} \mathrm{i}-\mathrm{p}$ 'ei, representing a cormorant fisher, is in the possession of Mr. Benjamin March, Detroit, to whom I am indebted for kindly placing at my disposal a photograph of it here reproduced in Plate XIV. The painting ( 46 by 22 inches) is on paper, in black ink on a blue background wash and some tan-orange in the foreground. It illustrates well the method of solitary fishing described above (p. 244). The bare-legged fisherman is cautiously propelling his five-bamboo raft with a long pole, and one of his two cormorants is spying the water for fish. The picture is inscribed in grass characters as follows: 康熙乙已元䆒前一日 鐵嶺 高其佩指戲, i.e. “Finger-play (finger-painting) of Kao K'i-p'ei of T'ie-ling (in Fung-t'ien fu, Sheng-king, Manchuria, place of his birth), done on the day before the first full moon of the year (the Feast of Lanterns) of the year $i$-se of the K'ang-hi period" (1665). As the artist died in 1734, he must have been very young when he sketched this picture; the date of his birth seems to be unknown. The date 1665, at any rate, is apt to rouse suspicion, and there may be something wrong about it and the entire legend; 1725 , an $i$-se year, would be more probable, but this falls within the Yung-cheng period. The year 1665 is separated from 1734 by 69 years; presuming that in $1665 \mathrm{Kao}$ was about 20 years old, he must have lived to the age of 89 ; this is not impossible, but it is harder to 
believe that in his youth he should have done this picture which bears the ear-marks of a work of maturity. Hirth (Scraps, p. 30) remarks that his best period seems to fall in the years 1700-15. Field Museum possesses a finger ink-sketch by him, representing two hawks fluttering around a bare tree-trunk with a date corresponding to 1685 , and another, undated, representing a carp swimming upstream and stretching its head out of the water. Both pictures are reproduced in Laufer, History of the Finger-print System, Smithsonian Report for 1912, plates 5 and 6 . Kao K'i-p'ei, as is well known, was a great exponent of the art of finger-painting, and was a really good artist.

The woodcut inserted in the $T^{\prime} u$ shu tsi ch'eng (XIX, chap. 45) shows a single bird perching on a rocky platform and overlooking the water; the figure is fairly exact, except the beak, the upper mandible of which is but slightly curved instead of terminating in a hook. The Pen ts'ao kang mu contains an engraving of a cormorant floating downstream with a small fish in its beak.

The San ts'ai t'u hui (1607, sect. Birds and Animals, p. 18) illustrates a cormorant on the bank of a river, a rather sorry specimen. The figure and scene are very similar to the illustration in the Cheng lei pen ts'ao (above, p. 224).

Good examples of Chinese ink-drawings of cormorant fishing are reproduced in the book of P. Korrigan (p. 38) and in Gray's China, II, opp. p. 297.

G. E. Freeman and F. H. Salvin (p. 328) entertained the idea that "this ingenious method of catching fish was most likely invented by the Chinese, and must be of very great antiquity, if we may judge by the representation in old China ware and other Chinese illustrations," to which is added in a foot-note, "We have seen cormorant fishing represented upon some ancient china cups at Leagram Hall, Lancashire, the seat of J. Weld, Esq."

On a white porcelain bowl of the Yung-cheng period (1723-35), brought from China by Mr. C. T. Yao of New York and presented to Field Museum by the American Friends of China, Chicago, various scenes in the occupations of fishermen are represented in enamel colors, among others a man standing in a boat and carrying on his shoulders a bamboo pole on which two cormorants perch (Plate XIII).

The $K u$ yü $t^{t} u p^{c} u$ (chap. 71, p. 13) illustrates a jade spoon or ladle terminating in a cormorant's head 珵玉 water receptacle in the shape of a tazza; evidently made in allusion 
to the cormorant wine-vessel of $\mathrm{Li}$ Po (see Pien tse lei pien, chap. 210, p. 5 , or $T s^{\prime} e$ yüan: lu-ts'e). A curious coincidence is represented by a spoon of the Eastern Dakota Indians, used in the feasts of the Medicine Lodge, which is provided with a handle carved to represent a cormorant's head (in Field Museum, Cat. No. 60411).

I do not enumerate the illustrations of cormorant fishing in China contained in the older European books, as these are reproduced by Gudger (I) with critical annotations and as in this age of photography they have but little scientific value.

The National Geographic Magazine of June, 1927 (p. 704), contains a good reproduction of an excellent photograph of a cormorant fisher taken by Dr. Camillo Schneider in western Yün-nan.

A photograph of cormorant fishing on the Wei-ho in Shen-si is reproduced by Clark and Sowerby (plate XX), without description; it shows a single fisherman standing astride on two small boats joined together, operating with three birds.

H. Kraemer's "Der Mensch und die Erde" (X, opp. p. 288) contains a colored plate entitled "Fishing with trained cormorants in China" after a painting by F. de Haenen. A fisherman is shown in the act of removing a fish from the bill of a cormorant which has just reached the edge of the boat; three birds are swimming in the water, and a confused mass of ropes is visible. The picture is rather fantastic than instructive. In the caption accompanying the plate it is said that the birds dive to a depth of 50 meters (!) and swim under water for two or three minutes with immense velocity. In the text which purports to trace the development of fishing all over the world nothing is said about cormorant fishing.

Yukihide Tosa (fifteenth century) has painted in colors an excellent scene representing cormorant fishing; a man in the boat governs two birds with strings held in his left hand, closely watching them; one bird is shown in the act of diving. A color reproduction of this picture is in Kokka, IV, No. 47, plate 1.

Kōrin Ogata, who died in 1716, is the creator of a masterly picture in ink on silk, showing an old fisherman in a boat with torchlight, eagerly watching his two cormorants in the water; one of the birds holds an ayu in its beak. The picture belongs to Baron Iwasaki of Tõkyo, and is reproduced in Kokka, XXX, No. 352, 1919, plate VI. It is said there that the theme was favorite with Körin and that this work belongs to his best.

Cormorant fishing at night in the Nagara River is illustrated in a colored print by Yeisen said to be "very rare" (reproduced in 
Japanese Color Prints of Lindsay Russell, New York, 1920, p. 22). It is evidently identical with No. 55 of the Sixty-nine Stations of the Kisokaido by Hiroshige and Yeisen.

A tsuba by Hironaga in Field Museum shows a fisherman with a lighted torch in the water, holding the ropes attached to a cormorant whose bill reaches up toward a fish ( $\mathrm{H}$. C. Gunsaulus, Japanese Sword-mounts, plate L, fig. 1).

Pichot's book illustrates seven boats fishing with cormorants in Lake Gifu, Japan; a lantern made in the same place and painted with cormorant fishing-boats; the count $\mathrm{R}$. de Najac holding his cormorant "Pole Nord" or "Carême"; and a French engraving of the eighteenth century showing falconers and pêcheurs au cormoran.

"Fishing with cormorants on the Nagara River, Gifu" is the subject of an illustration in an article on The Fisheries of Japan by Jihei Hashiguchi in Far Eastern Review, XIV, 1918, p. 319.

Dr. Gudger's article (II) contains many good reproductions of fine photographs representing cormorant fishing in Japan, many of these having been supplied by the Municipal Office of Gifu. 


\section{FOLK-LORE OF THE CORMORANT}

The Chinese folk-lore of the cormorant is not particularly interesting, but some notions entertained regarding the bird are worthy of mention. It is an old popular conception first pointed out by the calligrapher Wang Hi-chi 王義之 (A.D. 321-379) and by T'ao Hungking 陶宏景 (A.D. 452-536) that “this bird is not born from eggs, but spits its fledglings out of its mouth." Such an absurd idea could, of course, obtain only at a time when the bird's life was unknown, and no attempt at training it had been made. $\mathrm{Ch}^{\prime} \mathrm{en} \mathrm{Ts}^{\mathrm{s}}$ ang- $\mathrm{k}^{\mathrm{i}} \mathrm{i}$, the physician of the K'ai-yuian period (A.D. 713-741), writes that “this bird is viviparous 胎生 and brings its young forth from its mouth like the hare vomits its offspring; hence women at the time of childbirth, when holding this bird, will have an easy delivery." In the $Y u$ yang tsa tsu (chap. 16, p. 2) it is said, "The hare spits its young out, the cormorant spits its fledglings out."

The I wu chi of Yang Fu (T'ai p'ing yü lan, chap. 925, p. 8b), quoted on p. 221, adds to this superstition that the number of young born from the mouth is large, at least seven or eight, and that five or six are connected with one another and come out like a silk thread. In the Buddhistic dictionary $Y i$ ts'ie king yin $i$ the number of young ones brought forth from the mouth at one birth is given as eight or nine.

A parallel to the notion that holding a cormorant will bring about easy delivery occurs in ancient Japan, where for the same purpose a cormorant feather was grasped in the hand of a parturient woman (Aston, Nihongi, I, p. 98).

K'ou Tsung-shi冠宗㷈, in his Pents'ao yen $i$ 本草衍義 (chap. 16, p. 9, ed. of Lu Sin-yüan) written in A.D. 1116, gives the following account of the cormorant: “T'ao Yin-kü [T'ao Hung-king 陶宏景] asserts that this bird is not born from eggs, but vomits the fledglings out of its mouth. The people of the present time call it 'old waterduck.' The birds nest in large trees where they flock in large numbers. The trees in which they lodge for a long time will decay. Their droppings are poisonous. Pregnant women do not dare eat this bird on account of the fledglings being vomited out of its mouth. Ch'en Ts'ang-k'i, on the other hand, states that, in order to insure an easy childbirth, one should let a woman, when her hour approaches, hold a bird. While T'ao Siang-hi served as an official at Li-chou [in Hu-nan], there was a large tree behind the 
house of this gentleman. In the crown of this tree there were thirty or forty cormorant nests, where at evening the birds could be observed in the act of mating. Egg-shells of green color were found spread over the ground. How should this bird then obtain its young by vomiting them forth from its mouth! Such a thing has never been verified, and is nothing but baseless talk of the people."

This is one of the rare instances where a superstition is refuted by actual observation. S. Wells Williams (Chinese Repository, VII, 1839 , p. 542), referring to this belief, asserts that "Li Shi-chen very wisely puts such accounts among errata." Li Shi-chen, however, does not make any comment on this point; the criticism in question is solely due to $K^{\prime}$ ou Tsung-shi.

According to Wang Hi-chi, the ordure of the cormorant is white and dispels black spots on the face (apparently a skin-disease). According to the Fang shu 方書, evidently a book of medical prescriptions, cormorant's ordure is called “water-flower of Shu" 蜀水 花, it is rubbed into a powder and administered in water; it has the effect of causing men to renounce wine; the bird's head is a good remedy for fish-bones sticking in the throat (Ko chi king yüan, chap. 80,p. 3b). According to the Pen ts'ao kang mu, the "water-flower of Shu" is even mentioned in the Pie lu, and T"ao Hung-king comments, "It is plentiful in the valleys with streams; it is necessary only to get hold of it oneself, as what is offered in the markets cannot be trusted."

As the cormorant is able to swallow a fish, bone and all, it is easily understood that in the pharmacopoeia parts of the bird are recommended as relieving one from fish-bones sticking in the throat. T'ao Hung-king prescribes for this purpose the bird's bones to be burnt and mixed with lime and water; this medicine will force fishbones down the throat. Fan Wang 范汪, a physician, at the time of the Eastern Tsin dynasty (A.D. 317-419) recommends to swallow a cormorant's beak or to burn a cormorant's wing (prepared in the same manner as the bones previously) as a remedy against choking from fish-bones; even an inch square of a cormorant administered will bring the bone down, if only the bird's name is called out ( $T^{\prime} a i$ p'ing yü lan, chap. 925, p. 9). Li Shi-chen extols the bird's crop which must be swallowed, as very efficient for the same purpose.

Finally the cormorant appears in one story as a rain bird. In A.D. 797, at the time of a drought, prayers for rain were offered in the Dragon Hall of the Hing-k'ing Palace 祈雨于興慶宮龍堂, when a flock of white cormorants appeared above a pond, grouped as though conducting the imperial barge; on the following morning 
it rained ( Nan pu sin shu南部新書, written by Ts'ien Yi 鈛易 about A.D. 975, chap. 丙, p. 2b, ed. of Yüe ya t'ang ts'ung shu. The story is told with some greater detail in Kiu T'ang shu; see T'ai p'ing yü lan, chap. 925, p. 8b, or Yüan kien lei han, chap. 427, p. 8 b).

The description of the cormorants as "white" in the above text seems somewhat anomalous; perhaps there is confusion with herons. In England it was regarded as a sign of rain or wind when cormorants and gulls bathed themselves much, pruned their feathers, flickered or flapped their wings ( $\mathrm{J}$. Brand, Observations on the Popular Antiquities of Great Britain, III, 1888, p. 218).

Two popular sayings in the Amoy dialect are noted by Francken and De Grijs (Chineesch-Hollandsch Woordenboek van het Emoi Dialekt, p. 365, Batavia, 1882):

第籍項 $l o$ tsi $k^{\prime} 0 \mathrm{am}$, to have a ring around the neck like a cormorant; i.e., not to be wholly one's own master.

第未知尾復臭 lo tsi bu tsai bu ao ts'ao, the cormorant is not conscious of the odor penetrating from under its tail; i.e., not to see one's defects.

In England the voracity of the bird was proverbial, and Shakespeare likens to it a man of large appetite, as "the cormorant belly" (Coriolanus, I, 1), "cormorant devouring Time" (Love's Labour's Lost, I, 1), "this cormorant war" (Troilus and Cressida, II, 2). Compare T. F. Thiselton Dyer, Folk-lore of Shakespeare, 1884, p.108. Harting (Ornithology of Shakespeare, p. 260) writes, "Although Shakespeare mentions the cormorant in several of his plays, he has nowhere alluded to the sport of using these birds, when trained, for fishing; a fact which is singular, since he often speaks of the then popular pastime of hawking, and he did not die until some years after James I had made fishing with cormorants a fashionable amusement." E. Phipson (Animal-lore of Shakespeare's Time, 1883, p. 285) also writes that Shakespeare's references to the cormorant are only as an emblem of insatiable appetite.

The scanty information known to the ancients about the cormorant (if indeed it refers to this genus) has been collected by O. Keller (Die antike Tierwelt, II, p. 239).

A mythology of the cormorant exists only in ancient Japan (see above, p. 212) and among the Tlingit and some other Indian tribes along the northwest coast of America (for references see O. Dähnhardt, Natursagen, 1910, III, pt. 1, pp. 28, 29, 77, 105, 147, 232). 


\section{BIBLIOGRAPHY}

The earlier works on China which make reference to cormorant fishing have not been included here, as Dr. Gudger (I) has canvassed this ground, nor is mention made of modern works on China which have a casual reference to the subject without contributing anything new or worth while.

ANON.-Cormorant Fishing. East of Asia Magazine, Shanghai, II, 1903, pp. 95-97. Brief description inaccurate in several points. 4 ill.

BALL, J. DYER.-Things Chinese, 4th ed., Shanghai, 1903, pp. 181-183.

Belvallette, AlFred.-Traité de fauconnerie et d'autourserie. Suivi d'une étude sur la pêche au cormoran. Paris, 1903.

Brown, LucY Fletcher.-Fishing with the Birds of Gifu. Japan, XIV, 1925, pp. 23-24, 31. 3 ill.

Chamberlain, Basil H.-Things Japanese, 5th ed. London, 1905, pp. 105-108.

Cochrane, MaY L.-Harnessed Birds of Gifu. Asia, XXV, 1925, pp. 301-305.

Dabry DE Thiersant, P.-La pisciculture et la pêche en Chine. Paris, 1872, pp. 171-172, plate XIX, fig. 1.

David, Armand, and Oustalet, Emile.-Les oiseaux de la Chine. Paris, 1877, pp. 532-533.

Brief description of the species.

Doolitrle, Justus.-Social Life of the Chinese. London, 1868, pp 36-38. 1 ill.

Fauvel, Albert-Auguste.-Promenades d'un naturaliste dans l'archipel des Chusan et sur les cotes du Chekiang. Cherbourg, 1880.

Cormorant fishing: pp. 230-233 (valuable observations).

Floericke, K.-Kormoranfischerei. Kosmos, XI, Stuttgart, 1914, pp. 30-33.

Fortune, ROBERT.-I. Ten Years' Wanderings in the Northern Provinces of China. 2d ed., London, 1847, I, pp. 98-103. 3d ed., London, 1853, I, pp. 86-90.

II. Two Visits to the Tea Countries of China, 3d ed., London, 1853, I, pp. 86-90.

Freeman, G. E., and Salvin, F. H.-Falconry. Its Claims, History, and Practice.

To which are added Remarks on Training the Otter and Cormorant. London, 1859 .

Fishing with Cormorants, pp. 327-349.

Fishing with Otters, pp. 350-352.

Gray, John Henry, Archdeacon.-China, II, pp. 297-298. ill. London, 1878.

GUDGER, E. W.-I. Fishing with the Cormorant in China. The American Naturalist, LX, 1926, pp. 5-41. 16 ill.

II. Fishing with the Cormorant in Japan. The Scientific Monthly, XXIX,1929, pp. 5-38. 31 ill.

III. Fishing with the Otter. The American Naturalist, LXI, 1927, pp. 193-225. 6 ill.

HaHN, EduARD.-Die Haustiere. Leipzig, 1896, pp. 347-350.

HaRting, James E.-Essays on Sport and Natural History. London, 1883, pp. 423-440: Fishing with Cormorants.

IkeNoyA, S.-Cormorant Fishing. Japan Magazine, 1917, pp. 31-32.

JAMetel, MAURICE.-La Chine inconnue. Paris (Rouam), 1886. Chap. XII: Le faucon à poisson, son éducation, pp. 207-213.

Information on the training of the cormorant copied from Fauvel. 
Jordan, David StaRr. - Fishing for Japanese Samlets on the Jewel River. Outing, $\mathrm{XL}, 1902$, pp. 23-25. 1 ill.

Republished in Jordan's Guide to the Study of Fishes, II, New York, 1905, pp. 116-118; and Fishes, New York, 1925, pp. 142-144. 2 ill.

JouY, P. L.-On Cormorant Fishing in Japan. American Naturalist, XXII, 1888 , pp. 1-3.

Korrigan, PoL.-Causerie sur la pêche fluviale en Chine. Chang-hai, Imprimerie de la Mission Catholique, 1909.

An excellent booklet. Cormorant, pp. 39-43.

KURODA, NAGamichI.-Cormorant Fishing on the Nagara River. Japanese Magazine, Tokyo, XVI, 1926, pp. 303-320. 16 ill.

(Le comte) Le CouteulX de Canteleu.-La pêche au cormoran. Paris, Revue britannique, 1870 .

He was the owner of a flock of cormorants at his castle Saint-Martin.

Leonhardr, E.-Aus China. Deutsche Fischerei Correspondenz, V, 1901, June, p. 7 ; July, p. 3.

A few data on the training of the cormorant in China.

Pichot, Pierre-Amédé.-Les oiseaux de sport. Paris (A. Legoupy), 1903.

Cormorant: pp. 27-35; chiefly with reference to France and Japan.

RUPPRECHT PRINZ vON BAYERN.-Reise-Erinnerungen aus Ost-Asien. München, 1906.

Cormorant fishing in Tamagawa west of Tokyo, pp. 322-323.

Schмid, M.-Fortpflanzung des gemeinen Cormorans in Gefangenschaft. Der Zoologische Garten, XI, 1870, pp. 12-18.

Interesting data on the nesting habits and breeding of the cormorants.

SEebohm, Henry.-On the Cormorants of Japan and China. Ibis, 5th series, V, 1885 , pp. $270-271$.

Ornithological classification and description.

SmIth, Hugh M.-I. Japan, the Paramount Fishing Nation. Transactions American Fisheries Society, 33rd meeting, 1904, pp. 129-132. 4 ill.

II. The Fisheries of Japan. National Geographic Magazine, Washington, XVI, 1905, pp. 213-214. 3 ill.

Sokolowsky, AleXANDER.-Der Kormoran in seinen Beziehungen zur menschlichen Wirtschaft. Weltwirtschaftliches Archiv, Zeitschrift für allgemeine und spezielle Weltwirtschaftslehre, Jena, XII, 1918, pp. 315-320.

With a short bibliography.

Sourbets, G., and SAINT-MARC, C. DE.-Précis de fauconnerie, suivi de l'éducation du cormoran. Niort, Clouzot, 1887.

Sowerby, Alfred DE C.-The Cormorant in China. China Journal of Science and Arts, IV, 1926, pp. 72-74. 4 ill.

Special Catalogue of the Ningpo Collection of Exhibits. International Fishery Exhibition, Berlin, 1880. Also in Ibis, IV, 1880, pp. 375-376; and Special Catalogue of the Chinese Collection in Great International Fisheries Exhibition, London, 1883.

Information on cormorant by A. A. Fauvel.

Stone, JABEZ K.-Cormorant Fishing at Gifu. Japan, VIII, 1919, pp. 5-7, 44. 5 ill.

Williams, S. Wells.-Notices in Natural History: the Loo-sze or Fishing Cormorant. Chinese Repository, VII, 1839, Canton, pp. 541-543.

Very incomplete translation of the text of the Pen ts'ao. 


\section{INDEX}

An-hui, cormorant fishing in, 221, 222, 228

Aston, 212, 213, 255

ayu, 213, 231, 248, 253

Buddhists, attitude of toward cormorant fishing, 225

Chamberlain, 221

Ch'ang-t'ing hien chi, 209

Che-kiang, cormorant fishing in, 227, 242

Ch'en Hao-tse, 223, 250

Ch'en Ts'ang-k'i, 224, 225, 255

Cheng lei pen ts'ao, 224, 225, 252

Chi-li, cormorant fishing in, 230, 237

Cocks, 213

cormorant, Chinese terminology of, 208; folk-lore of , 255; geographical distribution of, 207, 227; iconography of, 251; Japanese terminology of, 211; process of domestication of, 236

Cormorant Cliff, 210

Cormorant Embankment, 210

Cormorant Islet, 210

Cormorant Lake, 210

Dabry de Thiersant, 238, 246, 258

De Guignes, 228, 243

Doolittle, 228

duet fishing, 244

eels, preferred by cormorants to other fish, 238

eggs, of cormorant, 237

egrets, tamed and kept in captivity, 249-250

England, cormorant fishing in, 206, 207

Er ya, 208, 214, 225

Er ya i, 217, 223, 225

Europe, cormorant fishing in, 206

falconry, cormorant fishing compared with, 218,229

Fan Chen, 218

Fan Wang, 256

Fang I-chi, 214, 219, 239

Fang shu, 256

Fauvel, 210, 227, 238, 241, 246, 258

fishermen's gild, 244

Florenz, 212

Fortune, 206, 227, 229, 238, 240, 241, 258

France, cormorant fishing in, 206

Fu-kien, cormorant fishing in, 227-228
Giles, 208, 209, 220, 221

group fishing, 244, 245

Gudger, 205, 213, 230, 232, 237, 249, $253,254,258$

Hahn, 236, 258

Hai-hou Tsie, 216

harness method of cormorant fishing in Japan, 234, 247

Harting, 206, 207, 229, 236, 257, 258

Hemeling, 211

Hing-hua fu chi, 208, 227

Hironaga, 254

Hiroshige, 254

Holland, cormorant fishing in, 206, 207

Ho-nan, cormorant fishing in, 228

Hu-nan, cormorant fishing in, 228; other fishing in, 249

Hu-nan fang wu chi, 228, 235, 237

Hu Tse, 215

Hüan Ying, 208

Hui Hung, 215

Hwa king, 223, 250

Hwang Ch'ao-ying, 218, 219

Hwang Kü-ts'ai, 251

I wu chi, 221, 255

Ikenoya, 213, 246, 258

Indo-China, cormorant fishing absent in, 235

James I, fishing with cormorants, 206, 257

Jametel, 246, 258

Japan, cormorant training and fishing in, $212,213,231,246-248$

Kao K'i-p'ei, 251, 252

Kiang-si, cormorant fishing in, 228

$\mathrm{K}$ 'in king, 221

Kojiki, 212

Korea, cormorant fishing absent in, 235

Korin Ogata, 253

Korrigan, 228, 244, 252, 259

K'ou Tsung-shi, 255, 256

Ku yü t'u p'u, 252

Kuroda, 213, 246, 259

Kwang-tung, cormorant fishing in, 228, 243

Kwei-chou, cormorant fishing in, 229

K'wei-chou fu chi, 219

$\mathrm{K}^{\prime}$ wei-chou t'u king, 217

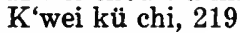

Kwo T'wan, 219

Lan chen tse, 215 
Lao-wa Tan, 229

Leng chai ye hwa, 215, 217, 219

Li Po, 221, 253

Li Shi-chen, 208, 224, 225, 256

Liu K'o, 217

Liu Yü-si, 215

Lo Yüan, 217, 223

Lu Ki, 221, 249

Lu nung shi, 215

Lu Tien, 250

Ma-kia-hiang t'ing chi, 242

Ma Twan-lin, 232, 233

Ma Yung-k'ing, 214, 215

Magnus, Olaus, 207

Man sou shi hwa, 216

Manyōshu, 213

Mao shi ts'ao mu niao shou ch'ung yü su, 221, 249

March, Benjamin, 251

Mendoza, 241

Milton, 209

Möllendorff, 209, 215, 217

Mong k'i pi t'an, 215, 217

Mong liang lu, 208

Nachod, 221

Nan Man ch'wan, 215, 216

Nan pu sin shu, 257

Neng kai chai man lu, 215, 219

Newton, 209

Nieuhoff, 210, 230, 237, 241, 242

Nihongi, 212

Ning-hua hien chi, 216, 239, 241, 242

Odoric, 205, 241, 243

ordure of cormorant, as a remedy, 224,

256 ; considered poisonous, 225,255 otter fishing, 249

Palladius, 209, 220

Parker, 210, 229, 233

pelican, 211

Pelliot, 208

Pen ts'ao kang mu, 208, 224, 252

Pen ts'ao kang mu shi i, 239, 252, 256

Pen ts'ao shi $j, 224,255$

Pen ts'ao yen i, 209, 255

Pi ki, 249

P'i ya, 215, 250

Pichot, 206, 207, 236, 247, 254, 259

Pie lu, 256

pig, sacred, 216

raft, for cormorant fishing, 244

raven, worshipped as a demon in Sech'wan, 216, 219

Reinhardt, 233,236

ring around cormorant's neck, significance of, 241,242

Ripa, 228

Salvin, 206, 207, 252

San ts'ai t'u hui, 252
Se-ch'wan, cormorant fishing in, 218, $230,231,243$

Se-ch'wan t'ung chi, 218, 219

Shakespeare, 257

Shan-tung, cormorant fishing in, 230

Shao-hing fu chi, 227, 250

Shao Po-wen, 220

Shen Kwa, 215, 217, 219

Shen-si, cormorant fishing in, 230,253

Siang su tsa ki, 215, 218

Sin siu pen ts'ao, 224

Sirén, 251

solitary fishing, 244, 249

Sowerby, 230, 237, 238, 248, 253, 259

Staunton, 242

sturgeon, 214

Sü Fang, 225

Sü po wu chi, 214

Su Shi, 250

Süan ho hwa p'u, 251

Sui shu, 212, 219, 232

Sung K'i, 249

Ta Ming i t'ung chi, 209

T'ai p'ing yü lan, $212,250,255,256$, 257

Tan-t'u hien chi, 209

T'an Ts'ui, 229

Tang-t'u, 221, 222

T'ao Hung-king, 255, 256

T'ao Ku, 221

team method of cormorant fishing in Japan, 234, 247

Tien hai yü heng chi, 229

Ting-hai t'ing chi, 227

Ts'ai Kwan-fu, 215

Ts'ai shi shi hwa, 215

Ts'ang kie p'ien, 208

Ts'e-k'i hien chi, 227

Ts'e yüan, defects of, 223

Ts'ing i lu, 209, 212, 214, 221, 245

Tsing k'ang siang su tsa ki, 218

Ts'ing-t'ien hien chi, 227

Tu Fu, 209, 214, 215, 217, 218

T'u shu tsi ch'eng, 212, 222, 225, 252

Tung chai ki shi, 218

T'ung ya, 214, 216, 217

Wang Hi-chi, 255, 256

Wang Mou, 215, 218, 219

Wang Wei, 221

Wen hien t'ung k'ao, 232

Wen kien lu, 220

Wieger, 226

Willes, 241,245

Williams, 208, 214, 256, 259

Wu-ho, reputed for breeding cormorants, 228

wu kwei, discussion of term, 214-221

Wu lei siang kan chi, 250

Wu li siao shi, 239

Wu Tseng, 219 
Yang Fu, 221, 255

Yang Shen, 217

Ye ko ts'ung shu, 215

Yeisen, 253

$Y_{i}$ ts'ie king yin i, 208, 255

Yu yang tsa tsu, 215, 255

Yü yin ts'ung hwa, 215

Yüan Chen, 216, 219, 221
Yüan kien lei han, 257

Yukihide Tosa, 253

Yule, 206

Yün-nan, cormorant fishing in, 229, 253

Yung-ch'un chou chi, 242

Zach, 221

\section{THE LBRARY of TH: OCT $8-1931$ \\ UNIVERSITY OF ILLINOIS.}




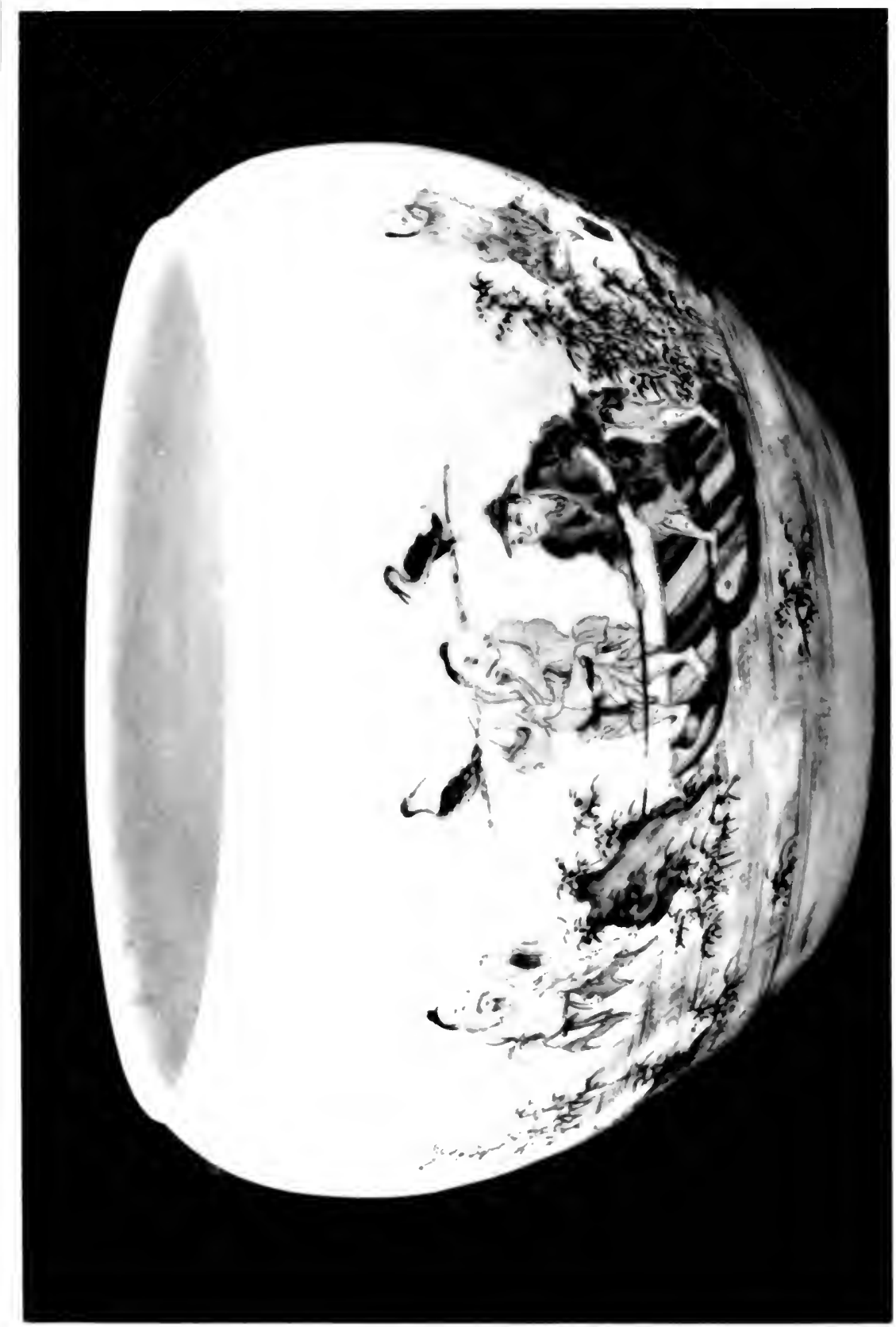

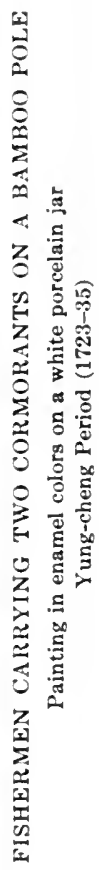


THE LIBRARY

OF YHE

UNIVERSITY OF ILLIMOIS 


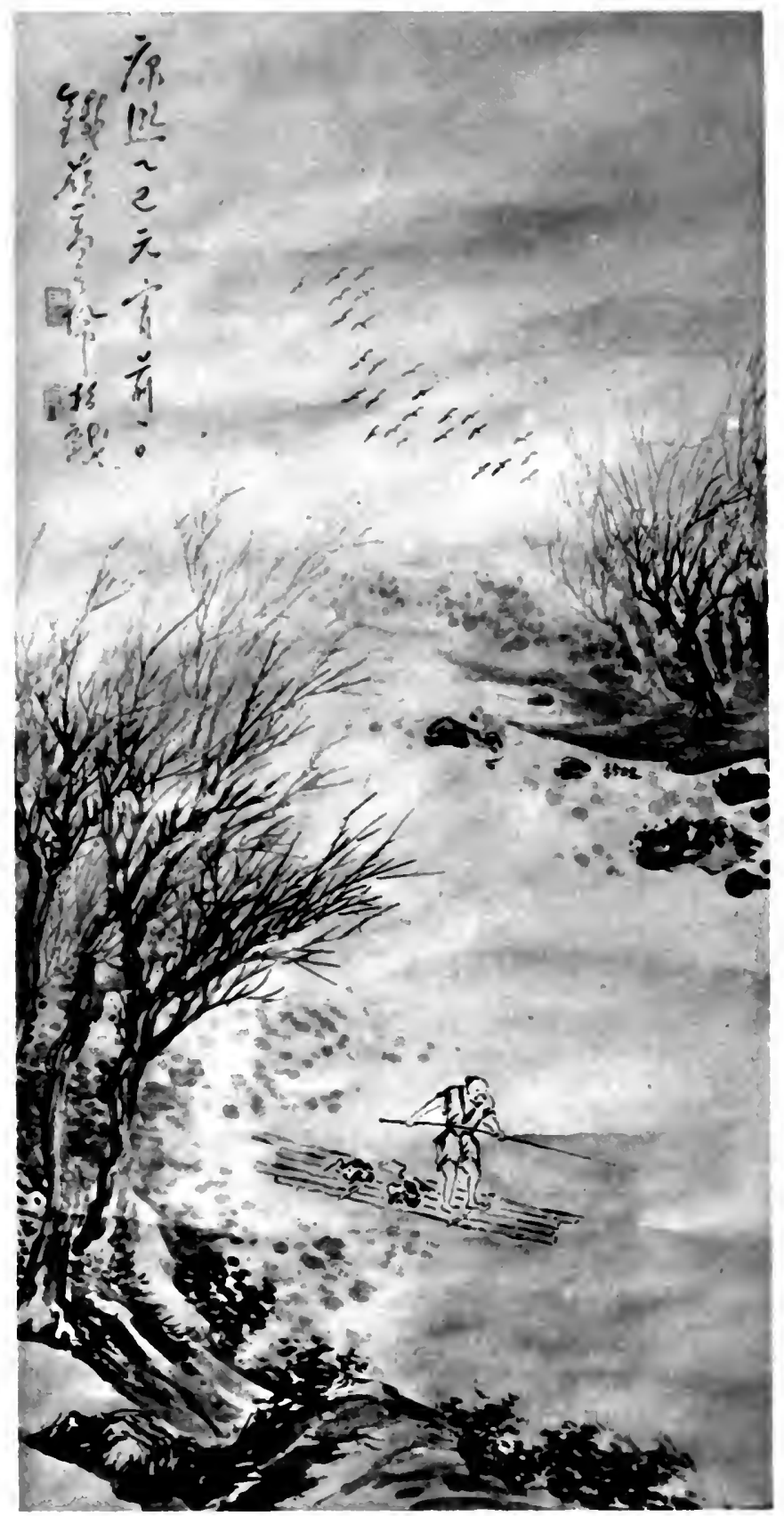

CORMORANT FISHER, FINGER-PAINTING BY KAO K'I-P'EI 
THE LIBRARY

OF THE

UNIVERSITY OF ILLINOIS 


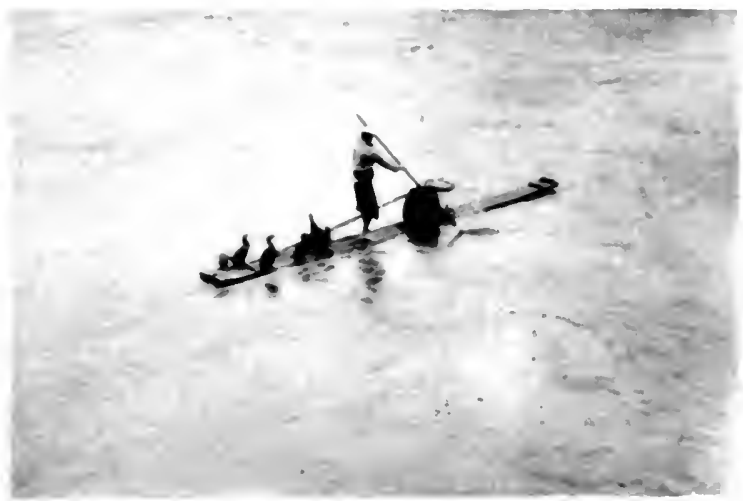

FISHERMAN ON BAMBOO RAFT WITH CORMORANTS

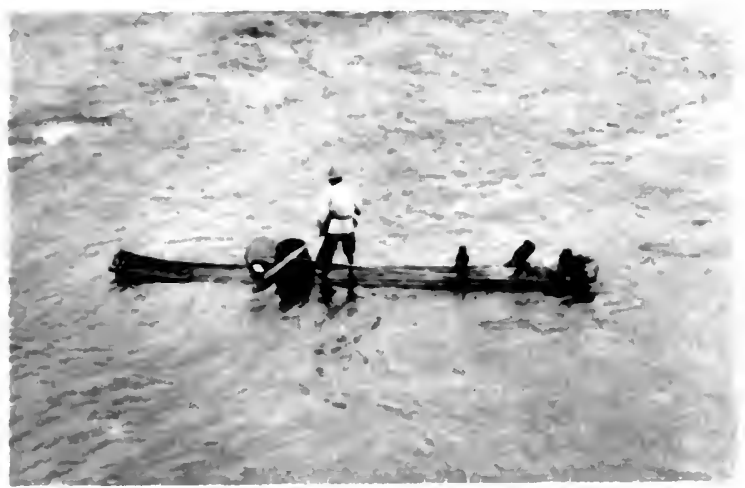

FISHING WITH CORMORANTS ON BAMBOO RAFT

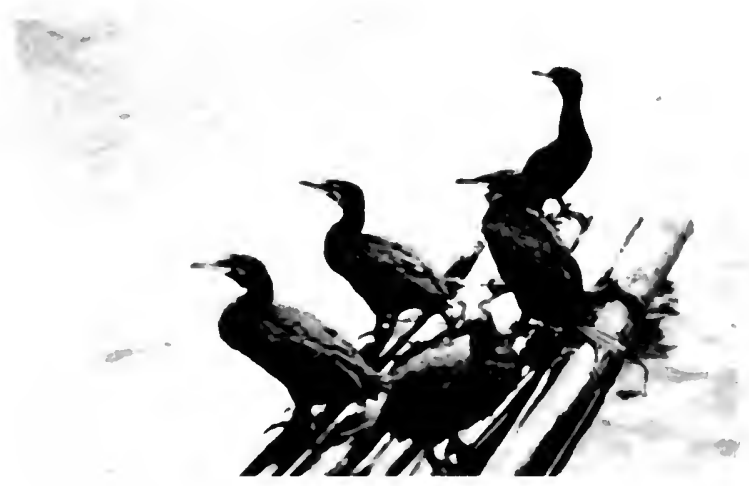

CORMORANTS PERCHING ON BAMBOO RAFT

Photographs taken by Floyd Tangier Smith on Min River near Fuchow, Fu-kien Province 


\section{THE LIBRARY}

OF THE

UNIVERSITY OF ILLINOIS 


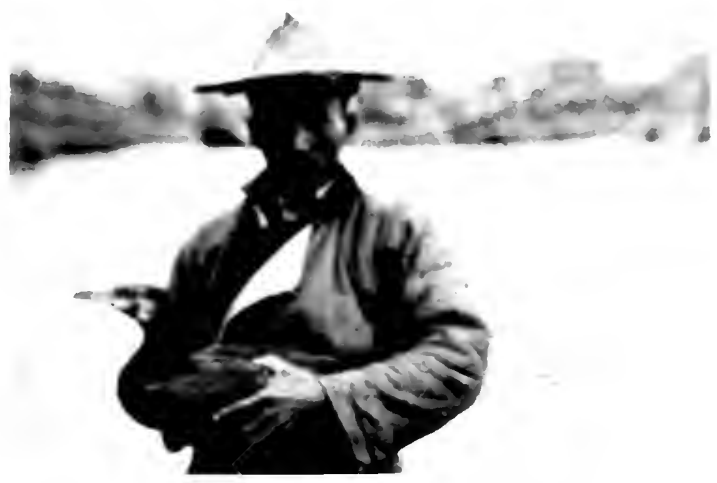

FISHERMAN HOLDING CORMORANT

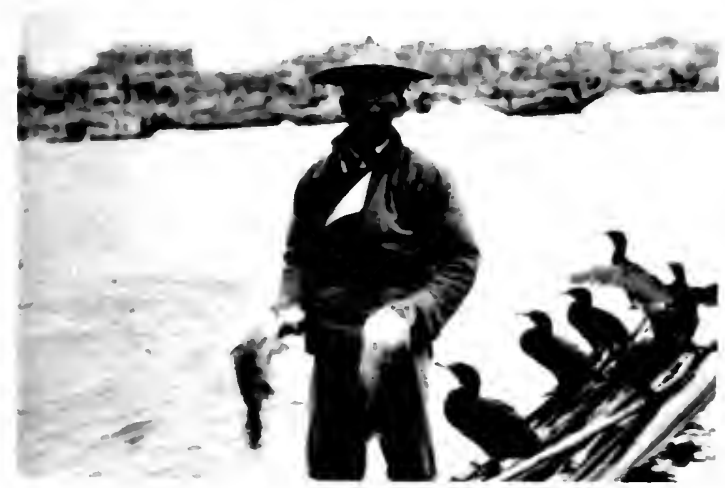

PLACING THE, CATCII IN A BASKET

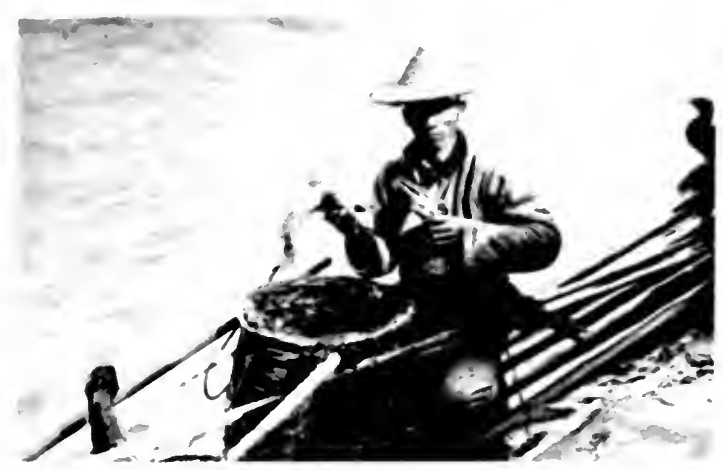

FEEDING THE CORMORANT AFTER THE CATCH

Photographs taken by Floyd Tangier Smith on Min River near Fuchow, Fu-kien Province 



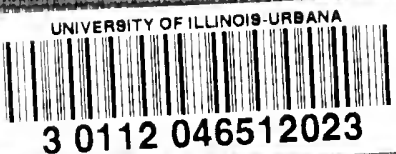

